Purdue University Purdue e-Pubs

\title{
Why Isn't the Doha Development Agenda More Poverty Friendly?
}

Thomas Hertel

Purdue University

Roman Keeney

Purdue University

Maros Ivanic

GOIC

Alan Winters

World Bank

Follow this and additional works at: http://docs.lib.purdue.edu/gtapwp

Hertel, Thomas; Keeney, Roman; Ivanic, Maros ; and Winters, Alan, "Why Isn't the Doha Development Agenda More Poverty Friendly?" (2007). GTAP Working Papers. Paper 35.

http://docs.lib.purdue.edu/gtapwp/35

This document has been made available through Purdue e-Pubs, a service of the Purdue University Libraries. Please contact epubs@purdue.edu for additional information. 


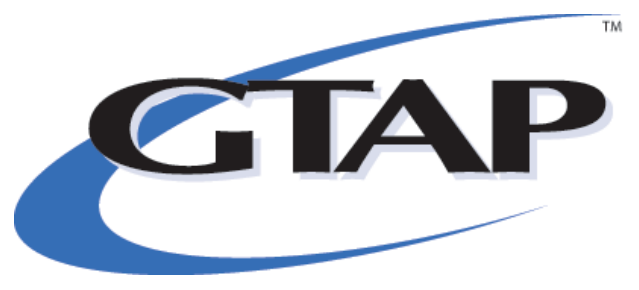

\title{
Why Isn't the Doha Development Agenda More Poverty Friendly?*
}

\author{
by \\ Hertel, Thomas** and Keeney, Roman \\ Purdue University, \\ Ivanic, Maros \\ GOIC, Doha \\ and \\ Winters, Alan \\ The World Bank
}

GTAP Working Paper No. 37

June 22, 2007

*The authors thank participants at the conference at Vanderbilt University for useful comments.

**Corresponding author: T.W. Hertel, Center for Global Trade Analysis, Purdue University, 403 West State Street, West Lafayette, IN 47906; hertel@purdue.edu 
Revised, June 11, 2007

\title{
Why Isn't the Doha Development Agenda More Poverty Friendly? *
}

\author{
by \\ Thomas W. Hertel** and Roman Keeney \\ Purdue University, \\ Maros Ivanic, GOIC, Doha \\ and \\ L. Alan Winters \\ The World Bank
}

*The authors thank participants at the conference on Globalization and the Developing Countries', held by the Graduate Program in Economic Development at Vanderbilt University, November 2006, for useful comments.

** Corresponding author: T. W. Hertel, Center for Global Trade Analysis, Purdue University, 403 West State Street, W. Lafayette, IN 47907; hertel@purdue.edu 


\title{
Why Isn't the Doha Development Agenda More Poverty Friendly?
}

\begin{abstract}
The breakdown of the WTO negotiations under the Doha Development Agenda has inspired critics to highlight the lack of effort on the part of rich countries to reform their agricultural policies. In this paper, we focus instead the poverty impacts of developing country tariff cuts - particularly those in agriculture. We argue that the Doha Development Agenda is fundamentally less poverty-friendly than it could be -- in large part due to the absence of tariff cuts on staple food products in developing countries. Such cuts would give the poor access to food at world prices, thereby reducing the cost of living at the poverty line. We also explore the contention that such tariff cuts will hurt the poor working in agriculture. Based on our analysis of the impacts of multilateral trade policy reforms on a sample of fifteen developing countries, we find there is some evidence of poverty increases in agriculture. However, such effects are minimized by ensuring that agricultural tariffs are cut in all developing countries. Overall, the povertyreducing impact of lower food prices dominates; we conclude that the Doha Development Agenda would be more poverty friendly if it were to include deeper cuts in developing country agricultural tariffs.
\end{abstract}

Keywords: WTO, Poverty, Trade Liberalization, Doha Development Agenda, Agricultural Trade 


\section{Introduction and Motivation}

The World Trade Organization's Doha Round of trade negotiations will be remembered for at least two characteristics. First, it was the first round to place development explicitly at the center of its business, as epitomized in its title "The Doha Development Agenda.” Second, it has revolved around agricultural trade liberalization to a much greater and more critical extent than any other round. These two bold innovations have certainly made negotiations more complex and sensitive and in the course of the five years' negotiations to date they have come to be intimately connected in the public and political perceptions. Such a connection is undoubtedly warranted but we will argue that it has not always been correctly understood. Although the agricultural component of a successful Doha round would enhance development, in the process of balancing the various pressures from the agricultural lobbies and the development advocates, the negotiators have not maximized its effect.

We adopt a limited, but widely used, operational definition of development - the reduction in the number of people in extreme poverty - and ask, for a medium-term horizon (3-5 years), how different elements of trade liberalization contribute towards this goal. We then show that the likely outcomes of the Doha round choose a sub-optimal mix. Several commentators including ourselves have observed that the emphasis on eliminating industrial countries’ agricultural export subsidies is not particularly povertyfriendly, because subsidies reduce food prices and many poor people are heavy net purchasers of food (e.g. Hoekman, Ng and Olarreaga, 2004; Anderson, Martin and Valenzuela, 2006, Hertel et al., forthcoming). This result is embedded in the current 
paper, but it takes a distant second place to another problem: the Doha round is set to require developing countries to undertake little agricultural trade liberalization and least developed ones (the poorest) to undertake none. It turns out that this too curtails the ability of the round to reduce poverty in developing countries, despite the fact that among negotiating parties it is the developing countries, and their advisors in the development community, who are insisting on such exemptions.

In fact, our results pose and resolve a paradox. Because of the patterns of protection involved, our analysis suggests that developing country poverty could be reduced both by liberalizing industrial countries’ agricultural trade, which will increase agricultural prices in developing countries, and by liberalizing developing countries’ trade, which will reduce them. We decompose the effects of the various trade liberalizations on poverty into effects acting via earnings, via the replacement of lost tax (tariff) revenue and via consumer prices. Developed country liberalization reduces poverty via its strong positive effect on the earnings of agricultural factors, which is generally not offset by the adverse effects of higher consumer prices. For developing countries' agricultural liberalizations, on the other hand, the earnings effects are mixed (partly because some countries export to other developing countries) and the revenue replacement effects adverse, but they are generally more than offset by the advantages of lower food prices.

The translation of global trade reforms into changes in poverty involves a long and torturous causal chain, which has so far entirely evaded econometric analyses of ex post data. The best we have econometrically are studies of specific steps - e.g. Golberg 
and Pavcnik (2003) on employment effects of trade reforms - or of specific events - e.g. Niimi, Vasudeva-Dutta and Winters (2006) on Vietnam's trade liberalization. And yet the prominence of the question in global debates means that the economics profession cannot legitimately evade the issue altogether. Thus in this and previous studies - Hertel and Winters (2006) and Hertel et al. (2007) - we use simulation techniques. We first construct plausible scenarios for the outcome of the Doha round, translating them into reductions in agricultural support at a very detailed level; from these we use a detailed global computable general equilibrium model - GTAP-AGR - to estimate likely effects on factor and commodity prices and government revenue in X countries and regions. Of these we specialize on fifteen developing countries for which we have detailed poverty, factor earnings and consumption data. The latter allow us to calculate the effects on poverty across seven strata of households per country of changes in ten factor rewards and in taxes and consumer prices. From these we construct a synthesis of likely national poverty consequences. The focus countries are based on data availability; they are neither randomly selected nor strictly representative of the developing world, but they cover three continents and a range of country sizes. Nevertheless, we look for results that re robust across this diverse group of countries, so overall we may be fairly confident that our findings are informative.

The basic scenarios and modeling approach in this paper are the same as in Hertel et al. (2007). However, whereas that article looked at rich-country income distribution as well as poor, and only at the net effects on developing country poverty, here we focus on the decomposition of the effects of different policies and the contrast between developed 
and developing country liberalization. It is, we believe, the first systematic attempt to look at the poverty dimension of the missing developing country liberalization in Doha. We turn now to our analytical framework, which emphasizes the decomposition of poverty results into its fundamental determinants.

\section{Analytical Framework}

\section{The Poverty Model}

There are many alternative approaches to estimating the poverty impacts of trade reforms (Winters et al.,2004; Hertel and Reimer,2005). The analytical approach used here builds on that of Hertel et al. (2004), which employs a sequential, macro-micro modeling strategy in which results from the global model are passed on to a series of microsimulation models. Our analysis begins with the specification of a utility function, and an associated consumer demand system, with which we can determine household consumption, as well as the maximum utility attainable by the household at a given set of prices and income. The utility of the household at the poverty line is defined as the poverty level of utility. Households with utility at or below this level are deemed to be in poverty. In this study, we follow Hertel et al. (2004) in using Rimmer and Powell's (1992a, 1992b, 1996), AIDADS system to represent consumer preferences, due to its capability to capture expenditure patterns across the global income spectrum. ${ }^{1}$ The following equation gives the budget share form of AIDADS:

\footnotetext{
${ }^{1}$ AIDADS has now been widely estimated on international cross section data, and it performs well out of sample, when compared to other demand systems (Cranfield et al., 2003b). This functional form may be viewed as a generalization of the popular, but restrictive, Linear Expenditure System (LES). Unlike the LES, AIDADS allows for non-linear Engel responses, while maintaining a parsimonious parameterization
} 


$$
\lambda_{n}=\frac{p_{n} \gamma_{n}}{y}+\frac{\alpha_{n}+\beta_{n} \exp (u)}{1+\exp (u)}\left(1-\frac{p^{\prime} \gamma}{y}\right) \forall n
$$

where $\lambda_{n}$ is the budget share of good $n, \alpha_{n}, \beta_{n}$, and $\gamma_{n}$ are unknown parameters, $u$ represents utility, $p_{n}$ is the price of good $n$, and $y$ is income. The following parametric restrictions are used to ensure well-behaved demands: $0 \leq \alpha_{n}, \beta_{n} \leq 1$ for all $n$, and

$$
\sum_{n=1}^{N} \alpha_{n}=\sum_{n=1}^{N} \beta_{n}=1
$$

Estimation of this demand system is undertaken using the 80 country, per capita consumption data set offered by GTAP, version 6.1 and the resulting parameters are reported in the first part of Table 1 . The demand system is then calibrated in order to permit it to precisely reproduce per capita demands in each country, as illustrated for the case of Peru in the second part of Table 1. This country-specific calibration technique is detailed in Golub (2006).

The AIDADS demand system is particularly attractive for poverty analysis, since it devotes two-thirds of its parameters to consumption behavior in the neighborhood of the poverty line. In particular, $\gamma_{n}$ is the estimated subsistence level of demand for commodity $n$, and $\alpha_{n}$ is the marginal budget share at the subsistence level of income, while the remaining $n$-dimensional parameter vector, $\beta_{n}$, is the marginal budget share at very high income levels. So, in the case of staple foods, we observe a non-zero (relatively 
large) value for both $\gamma_{n}$ and $\alpha_{n}$, whereas the value of $\beta_{n}$ is zero (see Table 1 - where the subsistence estimate is reported as a share of expenditure at mean prices and subsistence income). Thus, from (1), we see that the budget share for staple foods at low income (and hence low utility) levels will be high, whereas it will be low at high levels of per capita income and utility. In the case of Peru, for example, expenditures on food and clothing account for about $60 \%$ of budgets at the $\$ 1 /$ day poverty line.

With the parameters from (1) in place, we can now specify a well-defined household micro-simulation model in which households maximize per capita utility, subject to a per capita budget constraint, based on the households' overall endowments:

Choose $\left(x_{1 k}, \ldots, x_{i k}, \ldots, x_{n k}\right)$, where $i$ indexes the commodities and $k$ households, to maximize $u_{k}$

$$
\text { subject to: } \sum_{i=1}^{n} U_{i}\left(x_{i k}, u_{k}\right)=1 \text {, }
$$

$$
\begin{gathered}
U_{i}\left(x_{i k}, u_{k}\right)=\varphi_{i k}\left(u_{k}\right) \ln \left(\frac{x_{i k}-\gamma_{i}}{A \exp \left(u_{k}\right)}\right) \forall i \\
\varphi_{i k}\left(u_{k}\right)=\left[\alpha_{i}+\beta_{i} \exp \left(u_{k}\right)\right] /\left[1+\exp \left(u_{k}\right)\right], \text { and } \\
\sum_{i=1}^{n}\left(p_{i} x_{i k}\right)=Y^{k}=\sum_{j} W_{j} \bar{E}_{j}^{k}+T^{k} Y
\end{gathered}
$$


In this formulation, (2) - (4) define the implicitly additive AIDADS utility function with parameters $\alpha_{i}, \beta_{i}, \gamma_{i}$ and $A$, and marginal budget share as given in (4). Equation (5) is the per capita budget constraint, with income computed as the product of $W_{f}$, the wage paid, and $\bar{E}_{f}^{k}$, the (fixed) endowment to which this applies, plus any transfer payments, which are assumed be a constant share, $T^{k}$, of net national income, $Y$. Trade reform changes factor earnings and thereby income. When combined with the changes in commodity prices, utility maximizing households vary their mix of consumption, $x_{i k}$, and attain a new level of utility. If they were previously in poverty, and their per capita utility has now risen above the poverty level of utility, then the poverty headcount will fall, and vice versa.

There are many dimensions through which trade reforms might affect the poor in developing countries. In this paper we focus on the poverty headcount - the proportion of the population that falls below the poverty line -as a pragmatic way of summarizing the consequences of a range of policy reforms across fifteen developing countries for which we have been able to assemble comparable household survey data. These countries are listed in Table 1 and together they span the continents of Africa, Asia and Latin America. In the aggregate, they account for nearly 1 billion people, and more than 400 million poor (measured at the $\$ 2 /$ day poverty line; 150 million poor when evaluated at the $\$ 1 /$ day poverty line). While they are not a random sample, they do span a wide range of per capita income levels as well as differing degrees of industrialization, so , as we will see, earnings patterns of the poor in these fifteen countries vary greatly. 
A key finding in the work of Hertel et al. (2004) is the importance of stratifying households by their primary source of income. Farm households in developing countries often rely on the farm enterprise for virtually all of their income and the share of national poverty concentrated in agriculture-specialized households is quite high in the poorest countries in our sample - between one-quarter and one-half of the \$1/day headcount in Chile, Colombia, Indonesia, Malawi, Mozambique and Zambia. Not only are farm households in the poorest countries more likely to be specialized in farming, these specialized farm households also tend to be poorer, on average, than the rest of the population (Hertel et al.). The implication of this pattern of farm income specialization is that the poorest households in the poorest countries are more concentrated in agriculture and therefore more likely to benefit from producer price increases engendered by multilateral trade reforms. We follow Hertel et al. (2004) in identifying five household groups that rely almost exclusively (95\% or more) on one source of income: agricultural self employment, non-agricultural self-employment, rural wage labor, urban wage labor, or transfer payments. The remaining households are grouped into rural and urban diversified strata, leading to seven total strata. ${ }^{2}$

Hertel et al. (2004) solve the micro-simulation model given by (1) - (5) for each income level in each stratum, at each new price vector. This is computationally intensive and the results can be difficult to explain and generalize across countries. Instead, we

\footnotetext{
${ }^{2}$ A clear limitation of this approach stems from the rigidity of a given households' classification by earnings specialization. Obviously households mybe induced to change their specialization or diversify in response to changing relative factor returns. We believe that the relatively broad definition of strata circumvents this problem for the majority of households in the face of modest earnings changes. However, this important qualification will be further considered below in the results section.
} 
adopt a simpler, highly disaggregated poverty elasticity approach -- which focuses on changes in the neighborhood of the poverty line, and which lends itself to analysis and decomposition of a complex set of findings, in a relatively straightforward manner.

Begin with the cumulative density function of per capita income in region $r$ for the population stratum $s: F_{r s}(y)$. Then $F_{r s}\left(\bar{y}_{r}^{p}\right)$ computes the poverty headcount ratio when $\bar{y}_{r}^{p}$ is the level of income required to attain the poverty level of utility, $\bar{u}_{r}^{p}$, in region $r$, at initial prices. Since preferences and consumer prices are assumed to be the same across all strata within a given region, this poverty level of income is the same across all strata within a given country. We are interested in the elasticity of this poverty headcount with respect to a small change in the real income of households at the poverty line, in a given stratum $s$ : $d y_{r s}^{p}$. Assuming unchanging commodity prices, and given the function $F_{r s}\left(\bar{y}_{r}^{p}\right)$, this may be computed as follows:

$$
\varepsilon_{r s}=-\frac{d F_{r s}\left(\bar{y}_{r}^{p}\right) / d y_{r s}^{p}}{F_{r s}\left(\bar{y}_{r}^{p}\right) / y_{r s}^{p}}
$$

Table 2 reports these stratum-specific poverty elasticities for the fifteen countries in our sample. They range from a low of 0.0006 in the self-employed agriculture stratum in Zambia, where nearly all of the population is well below the poverty line, to a high of 3.63 in the urban diversified stratum of Brazil, where the population density at the poverty line is quite high. 
The proportional change in real income of households at the poverty line in stratum $s$ of region $r$ can be written as the income-share weighted sum of the households’ real after-tax factor earnings:

$$
\hat{y}_{r s}^{p}=\sum_{j} \alpha_{r s j}^{p}\left(\hat{W}_{r j}-\hat{C}_{r}^{p}\right)
$$

Where $\alpha_{r s j}^{p}$ is the share of income obtained from factor $j$ by households at the poverty line in stratum $s$ of region $r, \hat{W}_{r j}$ is the proportional change in after-tax earnings of factor $j$ in region $r$, and $\hat{C}_{r}^{p}$ is the proportional change in the cost of living at the poverty line in region $r$, obtained by evaluating equations (1) - (5) for the level of expenditure required to remain at the poverty level of utility. We can now express the proportional change in the poverty headcount in stratum $s$ of region $r$ as follows:

$$
\hat{F}_{r s}\left(\bar{y}_{r}^{p}\right)=\hat{H}_{r s}=\varepsilon_{r s} \cdot \hat{y}_{r s}^{p}=\varepsilon_{r s} \cdot \sum_{j} \cdot \alpha_{r s j}^{p}\left(\hat{W}_{r j}-\hat{C}_{r}^{p}\right)
$$

The earnings shares at the poverty line, $\alpha_{r s j}^{p}$, will play a critical role in our analysis and deserve some discussion before proceeding. Table 3 reports these shares across countries for the rural diversified household stratum. ${ }^{3}$ Note that, at the poverty line, earnings tend to be dominated by unskilled labor. As the rural households in this stratum are diversified in their earnings sources, they often show significant self-employment

\footnotetext{
${ }^{3}$ A complete set of shares for all strata are available in the reviewers' annex.
} 
income in both agriculture and non-agriculture, as well as unskilled wage earnings. With a few exceptions, the earnings shares of agricultural land and capital are negligible, as are the skilled labor shares. Transfer payments (both public and private) are an important source of income for the rural diversified household at the poverty line in many of the regions.

Having established the determinants of the stratum poverty headcount, we can now progress to the national poverty headcount, $H_{r}$, which can be expressed as a function of the stratum headcounts and stratum populations $\left(P O P_{r s}\right)$ :

$$
H_{r}=\left[\sum_{s} P O P_{r s} * H_{r s}\right] / P O P_{r}
$$

where $P O P_{r}=\sum_{s} P O P_{r s}$. So the proportional change in national poverty headcount is:

$$
\hat{H}_{r}=\sum_{s} \beta_{r s} * H_{r s} .
$$

Here:

$$
\beta_{r s}=\left[\left(P O P_{r s} * H_{r s}\right) / P O P_{r}\right] / H_{r}=\left(P O P_{r s} * H_{r s}\right) / \sum_{s}\left(P O P_{r s} * H_{r s}\right)
$$

is just the share of stratum $s$ poverty in nationwide poverty in region $r$. These shares are reported in Table 4 for our 15 focus countries. Agriculture specialized households and rural diversified households tend to dominate the poverty headcount, although exceptions are Colombia, Venezuela and Peru, where self-employed, non-agriculture households contain a large share of the poor. 
Combining (8) and (10) we get a useful expression for evaluating the change in the national poverty headcount in response to a small change in factor and commodity prices:

$$
\hat{H}_{r}=\sum_{s} \beta_{r s} \cdot \varepsilon_{r s} \cdot \sum_{j} \alpha_{r s j}^{p}\left(\hat{W}_{r j}-C_{r}^{p}\right)
$$

For purposes of subsequent analysis and discussion, it will be useful to further separate the tax component associated with the replacement of lost tariff revenue by another tax instrument. Hertel and Winters (2006) find that the choice of revenue replacement tax instrument can have a significant impact on the poverty results following trade reform. Here, we follow those authors in adopting the rather neutral approach of an endogenous, uniform factor income tax. Define the uniform ad valorem income tax on factor $j$ in region $r$ as follows:

$$
T A X_{r j}=t_{r} W_{r j}^{m} \cdot L_{r j}
$$

Where $t_{r}$ is the tax replacement instrument operating on market earnings, $W_{r j}^{m}$. Household earnings, net of taxes are thus equal to:

$$
W_{r j} \cdot L_{r j}=W_{r j}^{m} \cdot L_{r j}-t_{r} W_{r j}^{m} L_{r j}=\left(1-t_{r}\right) W_{r j}^{m} L_{r j}=T_{r} W_{r j}^{m} L_{r j}
$$

where $T_{r}$ is the power of the source-generic replacement income tax in region $r$. With fixed endowments, the proportional change in after tax income, is simply given by:

$$
\hat{W}_{r j}=\hat{T}_{r}+\hat{W}_{r j}^{m}
$$


Substituting (14) into (11) we have the following decomposition of changes in the poverty headcount in region $r$ into market earnings, replacement tax, and cost of living components:

$$
\hat{H}_{r}=\sum_{s} \beta_{r s} \cdot \varepsilon_{r s} \cdot \sum_{j} \alpha_{r s j}^{p}\left(\hat{W}_{r j}^{m}+\hat{T}_{r}-\hat{C}_{r}^{p}\right)
$$

Finally, since only relative prices matter in the general equilibrium model, it is useful to normalize market wages and the cost of living by a common, national, nominal variable that does not vary by stratum or earnings type. We choose net national income in the region $\left(y_{r}\right)$ for reasons that will become clear later on. Subtracting and adding $\hat{y}_{r}$ to the term in brackets in (15), we obtain the final decomposition of the national poverty impacts of a given change in the trade policy:

$$
\hat{H}_{r}=\sum_{s} \beta_{r s} \cdot \varepsilon_{r s} \sum_{j} \alpha_{r s j}^{p}\left[\left(W_{r j}^{m}-\hat{y}_{r}\right)+\hat{T}_{r}-\left(\hat{C}_{r}^{p}-\hat{y}_{r}\right)\right]
$$

Note at this point that the tax replacement and cost of living effects are earnings and stratum-generic, so (16) may be simplified as follows:

$$
\hat{H}_{r}=\sum_{s} \beta_{r s} \varepsilon_{r s} \sum_{j} \alpha_{r s j}^{p}\left(\hat{W}_{r j}^{m}-\hat{y}_{r}\right)+\varepsilon_{r} \hat{T}_{r}-\varepsilon_{r}\left(\hat{C}_{r}^{p}-\hat{y}_{r}\right)
$$

where we make use of the fact that $\sum_{j} \alpha_{r s j}=1$ and we define the national poverty elasticity as the poverty share-weighted sum of the stratum elasticities: $\varepsilon_{r} \equiv \sum_{s} \beta_{r s} \varepsilon_{r s}$. In subsequent analysis the first term on the right-hand side of the (17) will be referred to as the earnings effect of trade policy on poverty. It will vary by stratum, and is therefore the 
most complex term in the analysis. The second term is the poverty effect of tax revenue replacement, and the final term is the effect of the changing cost of living on poverty.

For expository purposes, let us now consider how (17) will be affected by three different developments: a rise in the unskilled wage rate, a fall in the power of the tax, and a rise in the price of staple foods. Since unskilled wages represent an important part of per capita income (recall Table 3), $\alpha_{r s j}^{p} \square 0$, a rise in the wage rate, relative to $y$, will boost income substantially, thereby moving some households across the poverty line. The proportional change in stratum headcount will depend on the density of the stratum population in the neighborhood of the poverty line, as captured by $\varepsilon_{r s}$. If this density is high, and the stratum also contains a large share of the nation's poor, as captured by $\beta_{r s}$, then there will be a relatively large reduction in the poverty headcount, ceteris paribus. Of course, other factors may change as well. If tariffs are cut, we expect that the income tax, $t_{r}$, will rise, so that $\hat{T}_{r}<0$, thereby inducing a rise in poverty. Finally, if trade liberalization results in a rise in staple food prices, for which $\lambda_{n} \square 0$ (recall Table 1), then we expect a rise in the cost of living at the poverty line, relative to net national income, will raise poverty in region $r$. In light of the fact that trade reforms considered here change all the relative prices as well as tax revenues, the decomposition offered by (17) is quite important for understanding the underlying determinants of a change in the national poverty headcount. 
Having outlined the “drivers” of poverty changes in our analytical framework, we turn now to the general equilibrium framework that will determine how these factor prices, commodity prices and taxes change as a function of trade policies.

\section{The Global General Equilibrium Model}

Our starting point for the global, general equilibrium analysis of the impacts of trade policy is the GTAP version 6.1 data base (Dimaranan, 2007). Virtually all contemporary analyses of the Doha Development Agenda start at this same point. Data availability is easily the most limiting resource for global analysis and GTAP version 6.1 represents the only data base covering global economic activities with bilateral trade and protection data that reflects tariff preferences. This also permits us to draw on the carefully constructed Doha reform scenarios developed and utilized in the recent books by Anderson and Martin (2006), and Hertel and Winters (2006). ${ }^{4}$ These scenarios also involve a pre-experiment in which key trade policies are updated to 2005, and it is from that benchmark that the trade liberalization experiments are undertaken.

Our modifications to the standard GTAP model focus on features that enhance analysis of agricultural reforms and simulation of poverty impacts. We retain the simplistic yet empirically robust assumptions of constant returns to scale and perfect competition typically featured in agricultural trade studies. ${ }^{5}$ The remaining modifications

\footnotetext{
${ }^{4}$ These tariff cutting scenarios are now available on the GTAP web site to those wishing to replicate this work. For purposes of this paper, we have used scenarios S0 (pre-simulation with China's WTO accession, EU enlargement, etc.) and S8: the central Doha scenario used in the Hertel-Winters volume.

${ }^{5}$ Francois et al. (2004) introduce monopolistic competition in the manufacturing sector into their analysis of WTO reforms. The resulting variety and scale effects generally boost the gains to rich countries and dampens the gains to poor countries from rich country reforms. However, this makes their model less stable, and, given our focus on agricultural reforms, this feature seems less critical.
} 
are aimed at permitting us to shed new light on the distributional consequences of WTO reforms - focusing particularly on unraveling the puzzle of why the Doha Development Agenda is not more poverty friendly.

On the demand-side of the model, we ensure consistency by modifying the global model to incorporate the demand system (1) used in the poverty module. Thus, aggregate preferences are consistent with the preferences used to evaluate the impact of price changes on households at the poverty line - although expenditure patterns obviously differ across regions due to differing per capita income levels.

The other modifications relate to the factor markets. Ever since the work of T.W. Schultz (1945), economists have recognized the importance of off-farm factor mobility in determining farm incomes. The limitations of agricultural labor markets have also been prominently featured in the development economics literature, as an explanation for the very low level of agricultural supply response (de Janvry et al., 1991). Modeling the complex processes leading to limited farm/non-farm, rural/urban mobility for the full range of countries in our model would be a lifetime project, so instead, we specify a constant elasticity of transformation function which "transforms” farm-labor into nonfarm labor and vice-versa. This transformation function permits wages to diverge between the farm and non-farm sectors, a key driver for our distributional analysis. We apply the same approach to the capital market, postulating a transformation function between agricultural and other capital. With segmented factor markets, the impact of reduced subsidies to agriculture in the rich economies will not be shared equally between the farm and non-farm labor forces or between farm and non-farm capital owners and 
similarly for the benefits from higher farm prices in developing countries following rich country reforms. . In order to parameterize these CET factor mobility functions we draw on the OECD’s (2001) survey of agricultural factor markets.

We assume a constant aggregate level of land, labor, and capital employment reflecting the belief that the aggregate supply of factors is unaffected by trade policy. This is not the 'full employment' assumption sometimes ridiculed by advocates of structuralist models of development. Rather it assumes that aggregate employment is determined by factors such as labor market norms and regulation that are largely independent of trade policy in the long run.

The income sources in Table 3 must be mapped to factor earnings in the general equilibrium model in order to make inferences about the poverty impacts of trade reform. Agricultural labor and capital receive the corresponding farm factor returns from the general equilibrium model, as do non-agricultural labor and capital. Wage labor reported in the household surveys presents a problem, since we do not know how much of it is employed in agriculture vs. non-agriculture activities. For this reason, we simply assign to it the economy-wide average wage - a blend of the farm and non-farm wages. Finally, transfer payments are indexed by the growth rate in net national income (the reviewer's appendix offers elaboration on this choice). 


\section{Policy Scenarios}

Our attention in this paper is on the developing country poverty impacts of trade reforms undertaken in both rich and poor countries. We take these in two stages, focusing initially on the poor country poverty impacts of liberalizing agricultural policies in only the rich countries. We then contrast this with agricultural trade reforms in the poor countries. The latter have proven controversial - particularly with regard to their impact on poverty, with some policy makers emphasizing that lowering protection for agriculture in developing countries will hurt poor farmers, while others have argued that lower food prices will serve to reduce poverty. We will use the poverty decomposition outlined above to identify both the earnings and spending sides of the problem, thereupon assessing their combined impact on poverty in our sample of fifteen countries. Finally, we bring in non-agricultural reforms (in both rich and poor countries) to complete the global reform scenarios.

The Doha scenario considered in this paper derives from the so-called July 2004 Framework Agreement (WTO, 2004) as embodied in the core scenario from the Hertel and Winters volume (2006) and is summarized, along with the other policy scenarios considered in this paper, in Table 5. The first column of this table highlights the implications for cuts in support in the rich countries' agricultural sectors - the main focus of this paper. This Doha scenario assumes that industrial countries with domestic support in excess of 20 percent of production cut their bound commitments by 75 percent, while others cut by 60 percent. However, even with these ambitious reductions, the binding overhang - the gap between bindings and applied policies - as well as the inclusion of 
market price support concepts mean that effectively only five WTO members would be required to reduce actual support, based on 2001 notifications: Australia, EU, Iceland, Norway, and USA (Jensen and Zobbe, 2006). Export subsidies are the one area where bold cuts (full elimination) are on the table, and we assume this outcome in our Doha scenario. When it comes to developing countries (see column two) domestic subsidy bindings are cut by 40 percent. In this case, Jensen and Zobbe (2006) estimate that only Thailand's subsidies would be affected.

Agricultural tariffs in the rich countries are reduced using a tiered formula, with marginal cuts changing at 15 and 90 percent bound tariff rates. The marginal cuts are 45 percent on the first 15 percentage points of the tariff, 70 percent for the range between 15 and 90 percent, and 75 percent on the remainder. ${ }^{6}$ For developing countries, the inflection points are placed at 20,60 and 120 percent bound tariff levels in agriculture, with marginal cuts of 35, 40, 50 and 60 percent, respectively.

Of course, cross-sector trade-offs are at the heart of the WTO negotiations, so we also consider the impact of non-agricultural elements of a prospective Doha Development Agenda. Improved access to rich country manufactures markets, as well as access to the markets of other developing countries can have an important impact on the demand for unskilled labor, and hence poverty rates in the poor countries. Following Hertel and Winters (2006), we focus the attention of our non-agricultural shocks on market access (see column three of Table 5), since barriers to services trade and

\footnotetext{
${ }^{6}$ For example, a tariff of, say, $110 \%$ is cut by $74.45 \%:=[15 \% * 0.45+(90-15) \% * 0.70+(110-90) \% * 0.75]$. By applying the cuts at the margin we avoid the discontinuities implied by the July Framework.
} 
investment remain difficult to quantify and those WTO negotiations appear unlikely to yield significant changes in the near term. Specifically, non-agriculture tariffs are subjected to proportional cuts of 50 percent for developed and 33 percent for developing countries. The Least Developed Countries are not required to cut tariffs under this central scenario (see Anderson and Martin, 2006). As a consequence of these relatively ambitious tariff cuts in both farm and non-farm trade, average world-wide tariffs for all merchandise trade drop from $4.7 \%$ in the baseline to $3.2 \%$.

Throughout our analysis, we employ a macroeconomic closure which fixes the ratios of government spending, tax revenue, net national savings, and the trade balance, all relative to net national income. This (relatively standard) closure facilitates linking the aggregate and disaggregate welfare impacts of trade reform (see the Reviewer Appendix for an extended discussion of our closure assumptions and their implications).

\section{Results}

\section{Agriculture Liberalization by the Rich Economies}

We begin our discussion of model results by briefly considering the macroeconomic impacts of rich and poor country liberalization on our fifteen focus countries. These serve as an appropriate prelude to our detailed investigation of the poverty changes in these focus countries. Full liberalization of trade distorting agricultural policies in the rich countries generates sizable trade volume increases for rice, sugar and beef products where border protection is dominant (see Reviewer Appendices). In the coarse grains and cotton sectors we observe declines in world trade as output increasing domestic subsidies 
are eliminated and excess supplies are reduced. Under the partial reforms of the Doha scenario, full elimination of export subsidies and limited tariff reductions generate declining trade volumes in wheat and dairy products.

These volume changes serve to boost world prices for agricultural products in general, and border prices for the developing countries in particular. The resulting change in the terms of trade (ToT) is the primary channel through which rich country agricultural reforms impact developing countries. If a country is a net importer of food products and the world price of food products rises, then the ToT might be expected to deteriorate.

Table 6 reports the change in focus country ToT and welfare (as measured by the percentage change in real private national consumption). Consider first the case of Bangladesh, which experiences a 0.5\% ToT deterioration under Rich-Agr-Full liberalization, and a $0.2 \%$ ToT decline under the Rich-Agr-Doha scenario. This is primarily due to higher import prices for cotton, wheat and oilseeds. With a deteriorating ToT, Bangladesh can afford fewer imports for a given amount of exports, and real consumption is expected to decline. On the other hand, Brazil, with a $4.9 \%$ ToT appreciation, can now consume more imports, or export less and consume more domestic production, so its welfare rises.

Of course, the story is a bit more complex for two reasons. First, in a world of differentiated products, there is no single “world price” for a good. Even a commodity like rice is differentiated and many different prices can co-exist in the world market at one point in time. As a result it matters importantly whether rice is sourced from a country whose price is rising, for example due to the elimination of an export subsidy. 
This is the case we observe for dairy imports into Venezuela from the European Union and United States. Venezuela also suffers from higher import prices for manufactures from Brazil, since the latter country experiences a real appreciation. In short, Venezuela is an example of a country that experiences ToT and consumption losses due to the country specific pattern of imports. Overall, we find that the ToT deteriorate in seven of the fifteen focus countries in the case of full agricultural reform in the rich countries, and in eight of the fifteen countries in the case of the Doha reforms. The latter result follows from the greater emphasis of Doha on export subsidies to market access.

The second caveat to the simple "ToT drive welfare" story arises from the presence of domestic tax and subsidy distortions. Note in particular, that in the case of the Philippines (Rich-Agr-Full) and Peru (Rich-Agr-Doha), the ToT improve, but welfare falls. This stems from fact that these countries have domestic tax policies that favor agriculture, relative to industry. Therefore an expansion of agriculture at the expense of industry has an adverse effect on economic efficiency and overall welfare.

Now let us turn to the primary focus of this paper, namely the poverty impacts of these trade reforms. We make use of the poverty decomposition outlined in equation (17), working through this expression from the inside out, beginning with the fundamental “drivers” of poverty changes, namely factor prices, tax rate changes and the cost of living change, by region. We then translate the earnings changes into poverty changes by strata, using the earnings shares and poverty elasticities in (17). Finally, we aggregate across strata to examine the national poverty impacts in each region resulting from the effects of changes in earnings taxes and cost of living. This approach provides significant new 
insights into the contrasting effects of trade reforms in rich and poor countries, as well as Doha vs. Full Liberalization.

Table 7 reports the change in relative factor returns, cost of living and income tax rates, by country resulting from agricultural trade liberalization by the rich economies under the assumption of a $\$ 1 /$ day poverty line ${ }^{7}$. We first note that relative returns to factors employed in agriculture (land, labor and capital) increase throughout the sample, while returns to non-agriculture factors decline. Economy-wide returns to unskilled wage labor rise, while those associated with skilled wage labor fall. These results are to be expected, since rich country agricultural reforms tend to shift agricultural production from North to South, thereby boosting the demand for agricultural inputs and unskilled labor in general in developing countries. Observe that the impact on the "earnings" associated with transfer payments is zero, as these payments are indexed to net national income, which is also used to deflate all earnings types reported Table 7.

The broad earnings tendencies are neatly summarized across the sample of countries by computing the "sign consistency" of a given variable ${ }^{8}$ (e.g., agricultural unskilled wages). This is computed as the ratio of the average to the average absolute value of the price change. Since rich agricultural reforms boost unskilled wages in all countries, the sign consistency measure reaches its maximum value of 1.0 for these factors (see last row in the second block of the Table). On the other hand, when it lowers

\footnotetext{
${ }^{7}$ This assumption for the poverty threshold is maintained throughout our analysis.

${ }^{8}$ Hertel and Ivanic (2005) develop the sign consistency and average absolute value as summary measures of cross-region impacts.
} 
a relative price in all regions - as is the case with non-agriculture skilled wages, the sign consistency measure reaches its minimum value of -1.0. The most striking thing about the sign consistency of relative factor returns in Table 7 is the great consistency of effects across this diverse group of countries.

The second-to-last row in the second block of Table 7 reports another important summary variable: the Average Absolute Value (AAV) of the price changes. This tells us how large the price changes are, on average, across our sample of countries. Thus, we see that the earnings impact is largest for land, followed by agricultural unskilled labor, and then skilled labor and agricultural capital. The absolute size of the impacts on nonagricultural factor returns and economy-wide wages are much smaller. Thus we expect the earnings-driven poverty impacts from rich country agricultural liberalization to be greatest in strata where agricultural factors command large earnings shares.

The final two columns in Table 7 report the percentage changes in the power of the income tax and the cost of living at the poverty line. Since the rich agricultural reform scenarios involve no tariff reductions in developing countries, there is no need to raise income taxes to replace lost revenue. So the only tax changes are due to the interaction between trade, production and consumption volumes and the associated taxes. In this case, we see that, in most cases, income tax rates increase slightly, thereby reducing the power of the tax. From the next column, we see that the cost of living at the poverty line rises in all focus countries, save Malawi. Each of these factors has an adverse impact on poverty, ceteris paribus 
For purposes of comparison, we report the summary statistics from the rich countries' partial reforms under Doha ${ }^{9}$. Note that the SC summary measures share the same sign, but are somewhat more muted - i.e. the results are more mixed across the focus countries. Similarly, the AAV measures are considerably smaller. As a result, we expect the poverty impacts of the rich country agricultural liberalization to be broadly similar in sign between Full and Doha reforms, but considerably smaller in size under the partial reforms of the Doha scenario.

Table 8 computes the poverty impact, by stratum, due to the deflated factor price changes. These values are the product of stratum specific poverty elasticities and the share-weighted change in household earnings (i.e. the share weighted average of the earnings sources in Table 7). As expected, poverty falls in all of the agriculture strata, while rising in the non-agriculture strata. Due to the importance of unskilled wages in all strata and agricultural returns in the diversified strata, earnings-driven poverty falls in all the other strata. So we can conclude that, apart from those households specialized in selfemployment in non-agricultural activities, earnings impacts of rich country agricultural liberalization are favorable for poverty reduction. This general finding follows through in the following the Doha partial reform scenario as well - albeit with a slightly less sign consistency and much smaller AAV.

In order to determine the national poverty impacts, we must aggregate the earnings impacts across strata (weighting the stratum changes by the groups' share in national poverty), and combine this with the poverty impacts of changing taxes and

\footnotetext{
${ }^{9}$ Complete results from Doha experiments are available in the Reviewers' Appendix.
} 
consumer prices. Table 9 does so, reporting the national poverty impacts separately for earnings, taxes and cost of living changes, in addition to their sum, which is the total impact on the national poverty headcount. Earnings changes from rich country agricultural liberalization contribute to national poverty reduction in all cases. The rise in agriculture-related returns as well as unskilled wages is sufficient to reduce poverty, even in those countries where the non-agriculture stratum contains a relatively large share of the poor (e.g., Colombia and Peru). The tax effect is negligible as previously noted, while the cost of living effect contributes to a rise in poverty in all regions save one (Malawi).

With the earnings and spending effects working in opposite directions, it is now a question of relative size in determining the total impact on national poverty. From Table 9, we see that the earnings effect dominates in nine of the fifteen cases, and it is sufficiently large to boost the SC measure to -0.88 (recall that unanimous poverty declines across countries would yield a SC of -1.0). Thus we conclude that full agricultural liberalization in the rich countries is poverty reducing on average for this sample of countries. In contrast the partial rich country reforms of the Doha scenario yield summary measures at the bottom of Table 9, where we find a smaller SC measure of -0.55 , and an AAV about one-quarter the magnitude of full liberalization. Thus we conclude that rich country reforms under Doha are less poverty-friendly than they would be under full liberalization, and about one-quarter as large in absolute magnitude. This can be attributed to the heavy emphasis on elimination of export subsidies and the relatively modest cuts in tariffs and domestic subsidies (Hertel and Ivanic, 2005). 


\section{Agriculture Liberalization by the Developing Economies}

Next we consider the impacts of poor country agricultural liberalization following the same scheme as the previous section for rich countries. Table 10 reports the impacts by underlying “driver” in each focus economy. Note that now it is nonagricultural labor and capital, as well as skilled labor, that realize the largest post-reform gains. This is as expected, because the tariff cuts are now implemented in the developing countries and result in the loss of tariff revenue. The impact on deflated agricultural returns is mixed, with substantial declines in some cases, and modest rises in those cases where agricultural exports to other developing countries rise as a result of increased SouthSouth trade. With the exception of agricultural land and transfers (zero due to indexing), however, the SC summary measure is positive for all factors. Unlike the previous case, the tax and cost of living impacts are now consistent across countries, with income tax rates rising (to replace lost tariff revenue) and the cost of living falling as consumers get access to food at world market prices (SC $=-1.0)$.

As before, we aggregate the earnings effects across factors and translate them into poverty reductions, by stratum. These are reported in Table 11 . The stratum with the most consistent poverty reduction is now the set of households specialized in non-agricultural self-employment. The other strata show aggregate poverty reductions, but less consistently so. Not surprisingly, the largest AAV is for the agriculture specialized and rural diversified households as these are the groups most directly affected (on the earnings side) by the agricultural tariff cuts. This pattern of poverty reduction presents a striking contrast with the stratum impacts of RichAgr reforms. In the latter case, the non- 
agriculture stratum consistently experiences poverty increases. So combining agriculture reforms in the poor countries with those in the rich countries is quite appealing from a poverty point of view since they benefit different segments of the society.

Table 12 summarizes the national poverty impacts of poor country agricultural trade liberalization. The first column represents the poverty share-weighted sum of the percentage changes in stratum poverty headcounts from Table 11. Observing Table 12 we find that the earnings impacts on poverty, while mixed, are on balance poverty reducing. This is somewhat surprising in light of concerns about agricultural tariff cuts on the poor. However, the reader needs to bear in mind that these are the impacts prior to tax replacement. Once the income tax adjustment is introduced (next column), the earnings picture is less rosy. Indeed, in all countries excepting Brazil, income taxes rise and this has an adverse impact on poverty. Furthermore, the AAV of the tax rise is nearly half as large as the earnings effect, and it dominates the former for several of the focus countries.

Of course the primary benefit of agricultural tariff cuts with respect to poverty alleviation is access to food at lower prices. This effect is evident in the cost of living column, where the deflated cost of living falls in all regions except Brazil, where increased export demand in other developing countries boosts food prices. The sign consistency measure is -0.99 for the cost of living contribution to national poverty changes and the AAV measure of 0.82 is even larger than the earnings AAV. The results presented in this table demonstrate clearly the beneficial impact of developing country agricultural liberalization on poverty, through the lowering of food prices. 
The final column in Table 12 reports the total impact arising from agricultural trade reform in the poor countries, taking into account the combined earnings, tax, and cost of living impacts. It is striking to note that poverty falls in all but one country. And the SC measure of -0.91 indicates that these reforms are even more poverty friendly than the rich agricultural reforms in Table 9. On the other hand, the contribution of poor country agriculture tariff cuts under Doha, while also poverty friendly, are negligible in magnitude, as indicated by AAV $=0.09$, which is just one tenth of the AAV for full liberalization of developing country agriculture trade policies.

Table 13 summarizes the poverty outcomes under rich, poor and combined (Subtotal Agric. Reforms column) agricultural reforms. Here we see total poverty changes repeated from agricultural reforms as reported in Tables 9 and 12, along with their combined effect. Given the total impact of agricultural liberalization we see that our findings suggest that only Mexico and Uganda would see an increase in the poverty headcount attributable to agricultural reforms (due to rich country reforms for Uganda and reforms by both country classes for Mexico). Furthermore, the AAV summary measure of 1.91 indicating significant movement of persons across the poverty line due to agricultural reforms, with the impact of combined rich and poor country reforms significantly more important than either one of these sets of reforms taken alone. The sign consistency value of -0.93 is also higher than the either of the two sets of reforms alone and indicates that global agricultural trade reforms are heavily weighted in the direction of poverty alleviation. This outcome is a direct consequence of the fact that both 
developed and developing country reforms reduce poverty - but each tends to do so for a different segment of the population; their poverty benefits are complementary in nature.

Table 14 considers agricultural reforms undertaken under Doha (in the first three columns); we find that only seven of the fifteen countries realize a reduction in the poverty headcount due to partial agricultural reforms under the postulated Doha scenario. The limited poverty reduction impact is reflected in the small (one-third of full reforms) value for the AAV of 0.31 , and the lack of uniform cross-country reductions of these partial reforms is reflected in the more moderate -0.76 sign consistency value (recall that under full agriculture reforms this number was -0.91).

\section{Beyond Agricultural Liberalization}

We conclude the analysis by considering liberalization scenarios that involve tariff cuts in non-agricultural sectors in both the rich and poor countries. Adding tariff cuts in manufactures leads to significant increases in manufacturing trade under both full and Doha scenarios and for both developed and developing countries (see the Reviewers' Appendix for detailed results). Returning to Table 6, we consider now the group of columns reporting the aggregate welfare and terms of trade impacts of non-agricultural (Non-Ag. columns) reforms. We see very different terms of trade and welfare impacts than those stemming from Rich Agriculture reforms only. The terms of trade for the focus developing countries fall in more cases (9 of 15 cases), due to the expansion of poor country exports in the wake of own and other developing country tariff cuts, as well as the erosion of preferences in rich country manufacturing markets. However, welfare only falls for six of these countries, with efficiency gains dominating the ToT losses in 
the other three cases (Philippines, Vietnam and Zambia). In contrast, under Global Doha, there are fewer ToT losses, but also fewer (and smaller) welfare gains. These mixed aggregate welfare effects for developing countries from global trade reforms are quite comparable to those reported in other studies of the aggregate impacts of global trade reforms on developing countries (Francois et al., Anderson and Martin, Hertel and Winters).

The final two columns of Tables 13 (full reform) and 14 (Doha reforms) report on the focus country poverty impacts of non-agricultural reforms and the effect of these combined with agricultural reforms. The full reform of non-agricultural tariffs (column 4 of Table 13) contributes to a poverty increase in the majority of our focus countries. However, the AAV of 0.80 is less than the values for rich or poor agricultural full reform, indicating lesser absolute impact on poverty, and the sign consistency of 0.23 indicates that some of the large effects are actually seen on the poverty reduction side (note the importance of the large reduction in Venezuela in this calculation). In Table 14 these same impacts are reported for Doha reforms in non-agriculture and we see that the AAV is smaller, indicating less impact, but slightly more consistent $(\mathrm{SC}=0.32)$, indicating that the impact of the Doha reforms across this sample countries is somewhat less poverty friendly than full reform.

The final columns in tables 13 and 14 report the combined impact of all merchandise trade reforms on poverty in our focus countries. The full reforms reduce poverty in 9 of the 15 countries, with a Sign Consistency of -0.81 and an average absolute value of 1.96. On the other hand, Doha reforms reduce poverty in only 7 of the 15 
countries, with less Sign Consistency and an AAV only about one-fifth as large. Thus, we conclude that the Doha reforms only generate about one-fifth of the poverty change as Full reforms, and are considerably less poverty friendly. This stems from the fact that both the agriculture and the non-agriculture Doha reforms are individually less poverty friendly than the full reforms.

\section{Conclusion}

This paper has examined the likely poverty impacts of trade reforms under the Doha Development Agenda, and contrasted them with the poverty consequences of full reform. We expect partial reforms to generate smaller poverty responses than full reforms, and indeed we find this to be the case, with lower Average Absolute Values (about one-fifth as large) for national poverty changes across our fifteen focus countries. However, the two types of reforms are also qualitatively different. This is captured in our Sign Consistency measure, which reports how poverty friendly a given reform is, regardless of magnitude. By this measure, we judge that full reforms are nearly twice as poverty friendly as the Doha reforms.

There are two factors driving this result. The first is that RichAgr reforms under Doha emphasize those elements of policy reform - export subsidies and, to a lesser degree, domestic support -- that are less important to developing countries as a whole (Hertel and Keeney, 2006), and less favorable to poverty in particular (Ivanic, 2006). The latter is underscored by our comparison of the Sign Consistency of RichAgr reforms under Doha and Full Liberalization. Less well-understood is the second reason why the Doha scenario is not more poverty friendly - it largely omits tariff cuts in the developing 
countries themselves. Our analysis shows that this is the most poverty friendly aspect of global trade reform. And it effectively complements the poverty impacts of Rich country reforms. While the latter tend to raise food prices, the developing country reforms lower food prices for the poor, by reducing tariffs on these products. This generates rather widespread poverty reduction. 


\section{References}

Anderson, K., W. J. Martin and E. Valenzuela (2006). “The Relative Importance of Global Agricultural Subsidies and Market Access. Policy Research Working Paper 3900, World Bank.

Anderson, K., and W. Martin (eds). 2006. Agricultural Trade Reform and the Doha Development Agenda, Palgrave Macmillan and The World Bank, New York.

Cranfield, J.A.L., P.V. Preckel, J.S. Eales and Thomas W. Hertel, 2000. "On the Estimation of an Implicitly Additive Demand System,” Applied Economics, December, 32(15):1907-1915.

Cranfield, J. A. L., P. V. Preckel, J. S. Eales, and T. W. Hertel, 2003a. "Estimating Consumer Demand Across the Development Spectrum: Maximum Likelihood Estimates of an Implicit Direct Additivity Model,” Journal of Development Economics, (68):289-307.

Cranfield, J.A.L., J.S. Eales, T.W. Hertel, and P.V. Preckel. 2003b. "Model Selection when Estimating and Predicting Consumer Demand Using International, CrossSection Data,” Empirical Economics 28: 353-64.

de Janvry, A., M. Fafchamps, and E. Sadoulet. 1991. "Peasant Household Behavior with Missing Markets: Some Paradoxes Explained,” Economic Journal, 101: 14001417.

Dimaranan, B.D. 2007. Global Trade, Assistance and Protection: The GTAP 6 Data Base, Center for Global Trade Analysis, Purdue University.

Francois, J., H. van Meijl, and F. van Tongeren. 2005. “Trade Liberalization in the Doha Development Round,” Economic Policy, 20: 349-391.

Goldberg, P.K. and Pavcnik, N. (2003). "The Response of the Informal Sector to Trade Liberalization.” Journal of Development Economics v72, n2 (Special Issue Dec.): 463-496.

Golub, A., T.W. Hertel, H. Lee and N. Ramankutty. 2006. “Modeling Land Supply and Demand in the Long Run," paper presented at the Ninth Annual Conference on Global Economic Analysis, Addis Ababa, June 15-17, also available at: https://www.gtap.agecon.purdue.edu/resources/download/2628.pdf

Hertel, T.W. and M. Ivanic. 2006. "Understanding the Poverty Implications of the Doha Development Agenda,” mimeo, Center for Global Trade Analysis, Purdue University, W. Lafayette, IN. 
Hertel, T.W., M. Ivanic, P.V. Preckel, and J.A.L. Cranfield. 2004. "The Earnings Effects of Multilateral Trade Liberalization: Implications for Poverty,” World Bank Economic Review 18: 205-36.

Hertel, T.W., and R. Keeney. 2006. "What is at Stake: The Relative Importance of Import Barriers, Export Subsidies, and Domestic Support," Chapter 2 in Agricultural Trade Reform and the Doha Development Agenda, K. Anderson and W. Martin eds., Palgrave Macmillan and The World Bank, New York.

Hertel, T.W., and J.J. Reimer. 2005. "Predicting the Poverty Impacts of Trade Reform," Journal of International Trade and Economic Development, 14: 377-405.

Hertel, Thomas W. and L. Alan Winters (2006). Poverty and the WTO: Impacts of the Doha Development Agenda, World Bank and Palgrave

Hertel, Thomas, W., Roman Keeney, Maros Ivanic and L. Alan Winters (2007) "Distributional effects of WTO agricultural reforms in rich and poor countries," Economic Policy (forthcoming, April).

Hoekman, Bernard, Francis Ng and Marcelo Olarreaga (2004). “Agricultural Tariffs or Subsidies: Which Are More Important for Developing Countries?” World Bank Economic Review 18(2): 175-204.

Jensen, H.G., and H. Zobbe. 2006. "Consequences of Reducing Limits on Aggregate Measurements of Support," Chapter 9 in Agricultural Trade Reform and the Doha Development Agenda, K. Anderson and W. Martin eds., Palgrave Macmillan and The World Bank, New York.

Niimi, Yoko, Puja Vasudeva-Dutta and L. Alan Winters (2006). "Linking trade liberalisation and poverty: an illustration from Vietnam in the 1990s.” In Globalisation and Poverty: channels and policy responses, Maurizio Bussolo, Jeffery I. Round (eds). London; New York: Routledge.

Organization for Economic Cooperation and Development (OECD).2001. Market Effects of Crop Support Measures, OECD Publications, Paris.

Schultz, T.W. 1945. Agriculture in an Unstable Economy. McGraw Hill Press, New York.

Winters, L.A., N. McCulloch, and A. McKay. 2004. "Trade Liberalization and Poverty: The Evidence So Far,” Journal of Economic Literature, 27: 481-506. 
Table 1. Estimated Consumption Relationships: AIDADS Parameters

\begin{tabular}{lrrrrrr}
\hline \multirow{2}{*}{ Commodity Group } & \multicolumn{3}{c}{ International Estimates } & \multicolumn{3}{c}{ Calibrated-Peru } \\
& Subsist Shr & MBS-Poor & MBS-Rich & Subsist Shr & MBS-Poor & MBS-Rich \\
\hline Crops & 0.57 & 0.19 & 0.00 & 0.57 & 0.19 & 0.00 \\
Meat, Dairy, Fish & 0.00 & 0.16 & 0.05 & 0.00 & 0.14 & 0.05 \\
Food and Beverages & 0.10 & 0.20 & 0.07 & 0.10 & 0.21 & 0.08 \\
Textiles and Apparel & 0.00 & 0.07 & 0.05 & 0.00 & 0.12 & 0.10 \\
Utilities & 0.00 & 0.05 & 0.06 & 0.00 & 0.03 & 0.05 \\
Trade & 0.04 & 0.07 & 0.20 & 0.04 & 0.05 & 0.15 \\
Manufactures & 0.17 & 0.07 & 0.15 & 0.17 & 0.07 & 0.18 \\
Transportation and & & & & & & \\
Communication & 0.06 & 0.10 & 0.11 & 0.06 & 0.13 & 0.17 \\
Financial Services & 0.01 & 0.02 & 0.10 & 0.01 & 0.01 & 0.03 \\
Housing and Public & & & & & & \\
Services & 0.05 & 0.08 & 0.21 & 0.05 & 0.07 & 0.19 \\
\hline SOH
\end{tabular}

Source: Authors' estimates. 

Table 2. Elasticity of Poverty Headcount by stratum (\$1/day) wrt Total Income $\underline{\text { Strata }}$

\begin{tabular}{|c|c|c|c|c|c|c|c|c|}
\hline Country & Agric. & $\begin{array}{l}\text { Non- } \\
\text { Agric. }\end{array}$ & $\begin{array}{l}\text { Urban } \\
\text { Labor }\end{array}$ & $\begin{array}{l}\text { Rural } \\
\text { Labor }\end{array}$ & Transfer & $\begin{array}{l}\text { Urban } \\
\text { Diverse }\end{array}$ & $\begin{array}{l}\text { Rural } \\
\text { Diverse }\end{array}$ & $\begin{array}{c}\text { National } \\
\text { Elast. }\end{array}$ \\
\hline Bangladesh & 1.64 & 2.02 & 1.58 & 0.63 & 0.56 & 1.74 & 1.09 & 1.24 \\
\hline Brazil & 0.75 & 1.28 & 1.94 & 2.19 & 0.34 & 3.63 & 2.69 & 1.35 \\
\hline Chile & 1.90 & 2.24 & 2.06 & 1.55 & 2.45 & 2.29 & 2.60 & 2.18 \\
\hline Colombia & 0.79 & 0.60 & 1.73 & 1.72 & 0.93 & 1.14 & 1.00 & 0.82 \\
\hline Indonesia & 2.35 & 2.14 & 2.38 & 2.89 & 1.17 & 2.58 & 2.87 & 2.47 \\
\hline Malawi & 0.49 & 0.30 & 2.26 & 1.97 & 0.43 & 1.04 & 0.76 & 0.58 \\
\hline Mexico & 1.73 & 1.90 & 3.33 & 2.08 & 2.28 & 1.63 & 1.80 & 2.02 \\
\hline Mozambique & 0.28 & 0.94 & 0.97 & 0.76 & 0.48 & 1.58 & 0.99 & 0.64 \\
\hline Peru & 1.50 & 1.32 & 2.37 & 1.73 & 0.44 & 1.09 & 1.05 & 1.07 \\
\hline Philippines & 2.25 & 1.96 & 2.98 & 2.44 & 1.69 & 2.42 & 1.98 & 2.15 \\
\hline Thailand & 2.30 & 2.42 & 2.98 & 2.45 & 2.78 & 2.42 & 2.59 & 2.57 \\
\hline Uganda & 0.28 & 0.40 & 1.71 & 0.34 & 0.01 & 0.36 & 0.21 & 0.24 \\
\hline Venezuela & 0.69 & 1.16 & 2.57 & 2.17 & 0.01 & 1.72 & 1.53 & 1.20 \\
\hline Vietnam & 0.48 & 1.12 & 2.81 & 8.98 & 0.84 & 0.86 & 1.01 & 0.98 \\
\hline Zambia & 0.00 & 0.64 & 2.28 & 0.91 & 0.45 & 1.29 & 0.37 & 0.61 \\
\hline
\end{tabular}

Notes: Values in strata columns are elasticities of the poverty headcount with respect to changes in earnings. National elasticity in the final column is the poverty share weighted (see Table POVSHR) aggregate elasticity for each country. Elasticities estimated by authors using country specific household survey data. 

Table 3. Earnings Shares for Rural Diversified Stratum, \$1/day

\begin{tabular}{|c|c|c|c|c|c|c|c|c|c|c|c|}
\hline Country & Land & $\begin{array}{l}\text { Ag. } \\
\text { Unskilled } \\
\text { Labor }\end{array}$ & $\begin{array}{l}\text { Ag. } \\
\text { Skilled } \\
\text { Labor }\end{array}$ & $\begin{array}{l}\text { Non-Ag. } \\
\text { Unskilled } \\
\text { Labor }\end{array}$ & $\begin{array}{l}\text { Non- } \\
\text { Ag } \\
\text { Skilled } \\
\text { Labor } \\
\end{array}$ & $\begin{array}{c}\text { Wage } \\
\text { Labor } \\
\text { Unskilled }\end{array}$ & $\begin{array}{l}\text { Wage } \\
\text { Labor } \\
\text { Skilled }\end{array}$ & $\begin{array}{l}\text { Agricultural } \\
\text { Capital }\end{array}$ & $\begin{array}{c}\text { Non- } \\
\text { agricultural } \\
\text { Capital }\end{array}$ & Transfers & Total \\
\hline Bangladesh & 0.01 & 0.18 & 0.00 & 0.20 & 0.00 & 0.43 & 0.04 & 0.01 & 0.03 & 0.10 & 1.00 \\
\hline Brazil & 0.00 & 0.10 & 0.04 & 0.12 & 0.00 & 0.32 & 0.01 & 0.01 & 0.00 & 0.41 & 1.00 \\
\hline Chile & 0.05 & 0.16 & 0.00 & 0.02 & 0.00 & 0.35 & 0.00 & 0.07 & 0.00 & 0.35 & 1.00 \\
\hline Colombia & 0.00 & 0.22 & 0.00 & 0.30 & 0.00 & 0.22 & 0.02 & 0.00 & 0.02 & 0.21 & 1.00 \\
\hline Indonesia & 0.06 & 0.32 & 0.00 & 0.20 & 0.00 & 0.26 & 0.00 & 0.04 & 0.08 & 0.04 & 1.00 \\
\hline Malawi & 0.03 & 0.38 & 0.00 & 0.07 & 0.00 & 0.08 & 0.00 & 0.06 & 0.11 & 0.27 & 1.00 \\
\hline Mexico & 0.01 & 0.14 & 0.00 & 0.06 & 0.00 & 0.48 & 0.00 & 0.01 & 0.01 & 0.30 & 1.00 \\
\hline Mozambique & 0.01 & 0.43 & 0.00 & 0.07 & 0.00 & 0.07 & 0.00 & 0.02 & 0.20 & 0.20 & 1.00 \\
\hline Peru & 0.02 & 0.20 & 0.00 & 0.30 & 0.07 & 0.13 & 0.00 & 0.03 & 0.11 & 0.14 & 1.00 \\
\hline Phillippines & 0.22 & 0.00 & 0.02 & 0.14 & 0.01 & 0.30 & 0.01 & 0.12 & 0.08 & 0.11 & 1.00 \\
\hline Thailand & 0.04 & 0.21 & 0.03 & 0.03 & 0.01 & 0.24 & 0.07 & 0.02 & 0.02 & 0.35 & 1.00 \\
\hline Uganda & 0.14 & 0.15 & 0.00 & 0.06 & 0.00 & 0.09 & 0.06 & 0.26 & 0.14 & 0.10 & 1.00 \\
\hline Venezuela & 0.00 & 0.10 & 0.00 & 0.32 & 0.01 & 0.28 & 0.04 & 0.00 & 0.00 & 0.26 & 1.00 \\
\hline Vietnam & 0.01 & 0.09 & 0.00 & 0.14 & 0.00 & 0.00 & 0.00 & 0.00 & 0.55 & 0.21 & 1.00 \\
\hline Zambia & 0.01 & 0.03 & 0.00 & 0.20 & 0.00 & 0.43 & 0.05 & 0.03 & 0.13 & 0.12 & 1.00 \\
\hline
\end{tabular}

Source: Authors' calculations, based on household survey data. 

Table 4. Stratum Contributions to the \$1/day Poverty Population in each Country

\section{$\underline{\text { Strata }}$}

\begin{tabular}{lrrrrrrrr} 
Country & Agric. & $\begin{array}{c}\text { Non- } \\
\text { Agric. }\end{array}$ & $\begin{array}{c}\text { Urban } \\
\text { Labor }\end{array}$ & $\begin{array}{c}\text { Rural } \\
\text { Labor }\end{array}$ & Transfer & $\begin{array}{c}\text { Urban } \\
\text { Diverse }\end{array}$ & $\begin{array}{c}\text { Rural } \\
\text { Diverse }\end{array}$ & Total \\
\hline Bangladesh & 0.15 & 0.13 & 0.04 & 0.22 & 0.03 & 0.07 & 0.37 & 1.00 \\
Brazil & 0.14 & 0.09 & 0.24 & 0.15 & 0.32 & 0.04 & 0.03 & 1.00 \\
Chile & 0.26 & 0.01 & 0.09 & 0.09 & 0.28 & 0.15 & 0.12 & 1.00 \\
Colombia & 0.28 & 0.43 & 0.03 & 0.04 & 0.12 & 0.05 & 0.04 & 1.00 \\
Indonesia & 0.42 & 0.12 & 0.02 & 0.07 & 0.04 & 0.06 & 0.28 & 1.00 \\
Malawi & 0.54 & 0.11 & 0.00 & 0.03 & 0.07 & 0.01 & 0.25 & 1.00 \\
Mexico & 0.05 & 0.06 & 0.05 & 0.12 & 0.28 & 0.14 & 0.29 & 1.00 \\
Mozambique & 0.41 & 0.13 & 0.01 & 0.05 & 0.14 & 0.06 & 0.19 & 1.00 \\
Peru & 0.07 & 0.35 & 0.01 & 0.02 & 0.22 & 0.11 & 0.23 & 1.00 \\
Philippines & 0.12 & 0.06 & 0.03 & 0.05 & 0.03 & 0.23 & 0.49 & 1.00 \\
Thailand & 0.06 & 0.02 & 0.00 & 0.06 & 0.11 & 0.07 & 0.68 & 1.00 \\
Uganda & 0.10 & 0.04 & 0.00 & 0.03 & 0.02 & 0.07 & 0.75 & 1.00 \\
Venezuela & 0.08 & 0.24 & 0.17 & 0.10 & 0.28 & 0.08 & 0.05 & 1.00 \\
Vietnam & 0.04 & 0.11 & 0.00 & 0.00 & 0.05 & 0.10 & 0.70 & 1.00 \\
Zambia & 0.34 & 0.23 & 0.10 & 0.07 & 0.07 & 0.09 & 0.11 & 1.00 \\
\hline
\end{tabular}

Notes: Values are shares of the impoverished population that are specialized in a particular stratum of earnings. Shares are derived from country-specific household surveys. Total column reflects that entire poverty population is allocated among the seven strata. 
Table 5. Scenarios.

\begin{tabular}{|c|c|c|c|c|c|c|}
\hline & \multicolumn{2}{|c|}{$\begin{array}{c}\text { Rich } \\
\text { Agriculture }\end{array}$} & \multicolumn{2}{|c|}{$\begin{array}{c}\text { Poor } \\
\text { Agriculture }\end{array}$} & \multicolumn{2}{|c|}{$\begin{array}{c}\text { Non- } \\
\text { Agriculture }\end{array}$} \\
\hline & Doha & Full & Doha & Full & Doha & Full \\
\hline Tariffs & $\begin{array}{l}-45 \%, \\
-70 \%, \\
-75 \%\end{array}$ & $-100 \%$ & $\begin{array}{l}-35 \%, \\
-40 \% \text {, } \\
-50 \% \text {, } \\
-60 \%\end{array}$ & $-100 \%$ & $\begin{array}{c}- \\
50 \%(33 \% \\
\text { poor })\end{array}$ & $-100 \%$ \\
\hline $\begin{array}{l}\text { Agricultural } \\
\text { Export } \\
\text { Subsidies }\end{array}$ & $-100 \%$ & $-100 \%$ & n.a. & n.a. & n.a. & n.a. \\
\hline $\begin{array}{l}\text { Amber Box } \\
\text { Subsidies }\end{array}$ & $\begin{array}{l}-60 \%, \\
-75 \%\end{array}$ & $-100 \%$ & $-40 \%$ & $-100 \%$. & n.a. & n.a. \\
\hline $\begin{array}{l}\text { Green Box } \\
\text { Subsidies }\end{array}$ & n.a. & n.a. & n.a. & n.a. & n.a. & n.a. \\
\hline
\end{tabular}

Notes: Doha scenario is derived from Anderson and Martin (2006). Rich agriculture are component reforms undertaken in the wealthy countries. Agricultural tariffs are reduced via a tiered formula whereby the first fifteen percentage points of an ad valorem tariff are reduced by $45 \%$, the tariff rate between fifteen and ninety percent is reduced by $70 \%$, and the portion of the tariff above ninety percent is reduced by $75 \%$. A similar construct is in place for poor country agricultural tariffs with the tiers defined at tariff rates of twenty, sixty, and one-hundred and twenty percent. Amber box subsidy payments to non-land inputs and output are reduced at two levels: $75 \%$ reductions are required in countries where subsidies are greater than twenty percent of producer revenue, while countries falling below this threshold are required to reduce subsidy rates by only $60 \%$. Rich country non-agricultural tariffs are assumed to beh halved, develping countries' cut by 33.3\%. All full reforms require 100 percent reduction in the tariff or subsidy rate, and agricultural export subsidies are fully eliminated in both the Doha and Full reform scenarios. Green box subsidies (area and income based payments tied to historical production) are assumed to be unchanged. Least developed countries are required to make no liberalization reforms at all. 
Table 6. Welfare and Terms of Trade Results

\begin{tabular}{|c|c|c|c|c|c|c|c|c|c|c|c|c|c|c|c|c|}
\hline & \multicolumn{2}{|c|}{$\begin{array}{c}\text { Rich Agr. } \\
\text { Full }\end{array}$} & \multicolumn{2}{|c|}{$\begin{array}{c}\text { Rich Agr. } \\
\text { Doha }\end{array}$} & \multicolumn{2}{|c|}{$\begin{array}{c}\text { Poor Agr. } \\
\text { Full }\end{array}$} & \multicolumn{2}{|c|}{$\begin{array}{c}\text { Poor Agr. } \\
\text { Doha }\end{array}$} & \multicolumn{2}{|c|}{$\begin{array}{c}\text { Non-Ag. } \\
\text { Full }\end{array}$} & \multicolumn{2}{|c|}{$\begin{array}{c}\text { Non-Ag. } \\
\text { Doha }\end{array}$} & \multicolumn{2}{|c|}{$\begin{array}{c}\text { Total } \\
\text { Full }\end{array}$} & \multicolumn{2}{|c|}{$\begin{array}{l}\text { Total } \\
\text { Doha }\end{array}$} \\
\hline & ToT & $\mathrm{U}$ & ToT & $\mathrm{U}$ & ToT & $\mathrm{U}$ & ToT & $\mathrm{U}$ & ToT & $\mathrm{U}$ & ToT & $\mathrm{U}$ & ToT & $\mathrm{U}$ & ToT & $\mathrm{U}$ \\
\hline Bangladesh & -0.5 & -0.2 & -0.2 & -0.1 & -0.4 & 0.3 & 0.0 & 0.0 & -4.8 & -0.7 & 0.1 & 0.0 & -5.7 & -0.6 & 0.0 & 0.0 \\
\hline Brazil & 4.9 & 0.7 & 1.9 & 0.3 & 0.6 & 0.1 & 0.1 & 0.0 & -1.8 & -0.1 & 0.1 & 0.0 & 3.7 & 0.7 & 2.0 & 0.3 \\
\hline Chile & 0.7 & 0.1 & 0.2 & 0.0 & 0.2 & 0.1 & 0.0 & 0.0 & -0.3 & 0.0 & 0.0 & 0.0 & 0.6 & 0.3 & 0.2 & 0.0 \\
\hline Colombia & 1.2 & 0.0 & 0.6 & 0.0 & -0.4 & 0.1 & -0.1 & 0.0 & -2.3 & -0.6 & -0.2 & -0.1 & -1.5 & -0.5 & 0.3 & -0.1 \\
\hline Indonesia & -0.2 & -0.3 & -0.1 & -0.1 & 0.3 & 0.2 & 0.0 & 0.0 & 1.0 & 0.6 & 0.3 & 0.2 & 1.1 & 0.5 & 0.2 & 0.1 \\
\hline Malawi & 2.6 & 1.9 & 0.2 & 0.2 & 1.1 & 1.1 & 0.1 & 0.1 & -0.1 & 0.9 & 0.0 & 0.0 & 3.6 & 3.8 & 0.3 & 0.3 \\
\hline Mexico & -0.2 & -0.2 & -0.1 & -0.1 & -0.3 & 0.1 & 0.0 & 0.0 & -1.5 & -0.1 & -0.3 & -0.1 & -2.0 & -0.2 & -0.4 & -0.1 \\
\hline Mozambique & -0.4 & -0.6 & -0.1 & -0.1 & 0.6 & 1.8 & 0.1 & 0.1 & -0.2 & -0.1 & -0.1 & -0.1 & 0.0 & 1.2 & -0.1 & -0.1 \\
\hline Peru & 3.2 & 0.5 & 0.2 & 0.0 & -0.7 & 0.0 & -0.1 & 0.0 & -1.8 & 0.1 & 0.1 & 0.0 & 0.7 & 0.6 & 0.1 & 0.0 \\
\hline Philippines & 0.0 & -0.2 & -0.1 & -0.1 & -0.2 & 0.4 & 0.0 & 0.1 & -0.1 & 0.3 & 0.2 & 0.1 & -0.3 & 0.5 & 0.1 & 0.1 \\
\hline Thailand & 1.1 & 0.8 & 0.2 & 0.1 & 0.0 & 0.5 & 0.0 & 0.1 & 0.4 & 0.8 & 0.3 & 0.3 & 1.5 & 2.1 & 0.5 & 0.5 \\
\hline Venezuela & -0.4 & -0.1 & -0.2 & -0.1 & -0.2 & 0.0 & -0.1 & 0.0 & -1.6 & -0.2 & -0.4 & 0.0 & -2.2 & -0.3 & -0.7 & 0.0 \\
\hline Vietnam & 0.3 & 0.2 & -0.1 & -0.2 & -0.4 & 1.1 & -0.1 & 0.1 & -1.2 & 4.5 & -0.7 & -1.1 & -1.2 & 5.7 & -0.9 & -1.2 \\
\hline Zambia & -0.2 & -0.2 & 0.0 & 0.0 & 0.0 & 0.4 & 0.1 & 0.0 & -0.3 & 0.0 & -0.1 & 0.0 & -0.5 & 0.3 & 0.0 & 0.0 \\
\hline Average & 0.8 & 0.1 & 0.1 & 0.0 & 0.1 & 0.4 & 0.0 & 0.0 & -1.0 & 0.3 & 0.0 & 0.0 & -0.2 & 0.9 & 0.1 & 0.0 \\
\hline AAV & 1.1 & 0.4 & 0.3 & 0.1 & 0.4 & 0.4 & 0.1 & 0.0 & 1.2 & 0.6 & 0.2 & 0.1 & 1.7 & 1.2 & 0.4 & 0.2 \\
\hline Sign Cons. & 0.7 & 0.3 & 0.3 & -0.2 & 0.1 & 1.0 & 0.2 & 0.9 & -0.8 & 0.5 & -0.2 & -0.3 & -0.1 & 0.8 & 0.2 & -0.1 \\
\hline
\end{tabular}

Source: Authors' simulations 
Table 7. Drivers of Poverty Change across Focus Regions

\begin{tabular}{|c|c|c|c|c|c|c|c|c|c|c|c|c|}
\hline Countries & Land & $\begin{array}{c}\text { Ag. } \\
\text { Unskilled } \\
\text { Labor }\end{array}$ & $\begin{array}{l}\text { Ag. } \\
\text { Skilled } \\
\text { Labor }\end{array}$ & $\begin{array}{l}\text { Non-Ag. } \\
\text { Unskilled } \\
\text { Labor }\end{array}$ & $\begin{array}{l}\text { Non- } \\
\text { Ag } \\
\text { Skilled } \\
\text { Labor }\end{array}$ & $\begin{array}{c}\text { Wage } \\
\text { Labor } \\
\text { Unskilled }\end{array}$ & $\begin{array}{c}\text { Wage } \\
\text { Labor } \\
\text { Skilled }\end{array}$ & $\begin{array}{l}\text { Agricultural } \\
\text { Capital }\end{array}$ & $\begin{array}{c}\text { Non- } \\
\text { agricultural } \\
\text { Capital }\end{array}$ & Transfers & Taxes & $\begin{array}{c}\text { Cost } \\
\text { of } \\
\text { Living }\end{array}$ \\
\hline \multicolumn{13}{|l|}{$\begin{array}{l}\text { Rich Agric. } \\
\text { Full }\end{array}$} \\
\hline Bangladesh & 2.1 & 1.1 & 0.9 & -0.1 & -0.2 & 0.3 & -0.2 & 0.9 & -0.3 & 0.0 & 0.0 & 0.3 \\
\hline Brazil & 41.5 & 17.7 & 16.3 & -0.6 & -1.0 & 1.6 & -0.8 & 16.2 & -1.3 & 0.0 & -0.3 & 0.8 \\
\hline Chile & 13.5 & 7.0 & 6.3 & -0.2 & -0.5 & 0.9 & -0.5 & 6.3 & -0.6 & 0.0 & 0.0 & 0.7 \\
\hline Indonesia & 3.2 & 1.9 & 1.5 & -0.2 & -0.4 & 0.5 & -0.4 & 1.5 & -0.4 & 0.0 & 0.0 & 0.6 \\
\hline Malawi & 1.0 & 0.4 & 0.1 & -0.4 & -0.7 & -0.1 & -0.7 & 0.2 & -0.7 & 0.0 & -0.1 & -1.3 \\
\hline Mexico & 11.2 & 5.0 & 4.5 & 0.0 & -0.2 & 0.9 & -0.2 & 4.5 & -0.3 & 0.0 & -0.1 & 0.9 \\
\hline Mozambique & 2.2 & 1.1 & 0.9 & -0.2 & -0.3 & 0.2 & -0.3 & 0.9 & -0.3 & 0.0 & 0.0 & 0.5 \\
\hline Peru & 16.9 & 9.6 & 7.9 & -0.8 & -1.2 & 2.3 & -0.9 & 7.7 & -1.3 & 0.0 & -0.1 & 0.8 \\
\hline Philippines & 3.1 & 1.9 & 1.5 & -0.1 & -0.2 & 0.8 & -0.1 & 1.4 & -0.4 & 0.0 & -0.2 & 0.6 \\
\hline Thailand & 23.4 & 12.2 & 9.6 & -0.2 & -1.2 & 3.8 & -1.0 & 9.3 & -1.8 & 0.0 & -0.1 & 1.2 \\
\hline Uganda & 0.1 & 0.0 & 0.0 & 0.1 & 0.0 & 0.0 & 0.0 & 0.0 & 0.0 & 0.0 & 0.0 & 0.2 \\
\hline Vietnam & 4.9 & 2.7 & 2.3 & -0.3 & -0.5 & 0.4 & -0.5 & 2.3 & -0.4 & 0.0 & -0.1 & 0.3 \\
\hline Zambia & 1.8 & 1.0 & 0.8 & -0.1 & -0.1 & 0.2 & -0.1 & 0.8 & -0.3 & 0.0 & 0.0 & 0.2 \\
\hline Average & 9.2 & 4.6 & 3.9 & -0.2 & -0.5 & 0.8 & -0.4 & 3.9 & -0.6 & 0.0 & -0.1 & 0.5 \\
\hline AAV & 9.2 & 4.6 & 3.9 & 0.3 & 0.5 & 0.8 & 0.4 & 3.9 & 0.6 & 0.0 & 0.1 & 0.7 \\
\hline $\begin{array}{l}\text { Sign Cons. } \\
\text { Rich Agric. } \\
\text { Doha }\end{array}$ & 1.0 & 1.0 & 1.0 & -1.0 & -1.0 & 1.0 & -1.0 & 1.0 & -1.0 & 0.0 & -0.9 & 0.7 \\
\hline Average & 2.2 & 1.1 & 1.0 & 0.0 & -0.1 & 0.2 & -0.1 & 1.0 & -0.1 & 0.0 & 0.0 & 0.2 \\
\hline AAV & 2.5 & 1.3 & 1.1 & 0.1 & 0.1 & 0.2 & 0.1 & 1.1 & 0.2 & 0.0 & 0.0 & 0.2 \\
\hline Sign Cons. & 0.9 & 0.9 & 0.9 & -0.3 & -0.6 & 0.8 & -0.5 & 0.9 & -0.5 & 0.0 & -0.8 & 0.9 \\
\hline
\end{tabular}

AAA is the average absolute value of the data in the column; 'sign cons' is the "sign consistency" of the data - the ratio of the average to the average absolute value of the variable. 
Table 8 Earnings-Driven Percent Change in the Poverty Headcount (\$1/day) across Developing Country Strata, when Rich Countries Reform Agric. Policies

\begin{tabular}{lrrrrrrr}
\hline Countries & Agric. & $\begin{array}{r}\text { Non- } \\
\text { Agric. }\end{array}$ & $\begin{array}{c}\text { Urban } \\
\text { Labor }\end{array}$ & $\begin{array}{c}\text { Rural } \\
\text { Labor }\end{array}$ & Transfer & $\begin{array}{c}\text { Urban } \\
\text { Diverse }\end{array}$ & $\begin{array}{c}\text { Rural } \\
\text { Diverse }\end{array}$ \\
\hline Rich Agric. & & & & & & & \\
Full & & & & & & & \\
\hline Bangladesh & -0.3 & 0.0 & 0.0 & 0.0 & 0.0 & 0.0 & -0.1 \\
Brazil & -1.5 & 0.1 & -0.6 & -0.5 & 0.0 & -0.4 & -0.2 \\
Chile & -3.5 & 0.0 & -0.2 & -0.1 & 0.0 & -1.0 & -0.7 \\
Colombia & -1.2 & 0.1 & 0.0 & 0.0 & 0.0 & -0.1 & -0.1 \\
Indonesia & -1.8 & 0.0 & 0.0 & -0.1 & 0.0 & -0.1 & -0.7 \\
Malawi & -0.1 & 0.0 & 0.0 & 0.0 & 0.0 & 0.0 & 0.0 \\
Mexico & -0.5 & 0.0 & -0.1 & -0.2 & 0.0 & -0.3 & -0.7 \\
Mozambique & -0.1 & 0.0 & 0.0 & 0.0 & 0.0 & 0.0 & -0.1 \\
Peru & -0.8 & 0.4 & 0.0 & -0.1 & 0.0 & -0.3 & -0.5 \\
Philippines & -0.6 & 0.0 & -0.1 & -0.1 & 0.0 & -0.6 & -1.0 \\
Thailand & -1.5 & 0.0 & 0.0 & -0.5 & 0.0 & -0.7 & -7.0 \\
Uganda & 0.0 & 0.0 & 0.0 & 0.0 & 0.0 & 0.0 & 0.0 \\
Venezuela & -0.1 & 0.0 & -0.1 & 0.0 & 0.0 & 0.0 & 0.0 \\
Vietnam & -0.1 & 0.0 & 0.0 & 0.0 & 0.0 & -0.1 & 0.0 \\
Zambia & 0.0 & 0.0 & 0.0 & 0.0 & 0.0 & 0.0 & 0.0 \\
& & & & & & & \\
Average & -0.8 & 0.1 & -0.1 & -0.1 & 0.0 & -0.2 & -0.7 \\
AAV & 0.8 & 0.1 & 0.1 & 0.1 & 0.0 & 0.2 & 0.7 \\
Sign Cons. & -1.0 & 1.0 & -1.0 & -1.0 & -1.0 & -1.0 & -1.0 \\
Rich Agric. & & & & & & & \\
Doha & & & & & & & \\
Average & -0.2 & 0.0 & -0.0 & -0.0 & -0.0 & -0.1 & -0.2 \\
AAV & 0.3 & 0.0 & 0.0 & 0.0 & 0.0 & 0.1 & 0.2 \\
Sign Cons. & -0.8 & 0.8 & -1.0 & -0.9 & -1.0 & -1.0 & -0.9 \\
\hline Source: Authors' simulations & & & & & & \\
\end{tabular}


Table 9. Earnings-Driven Percent Change in the Poverty Headcount (\$1/day) across Developing Country Stratums, when Rich Countries Reform Agriculture

\begin{tabular}{lrrrr}
\hline Countries & Earnings & Taxes & $\begin{array}{c}\text { Cost } \\
\text { Of } \\
\text { Living }\end{array}$ & Total \\
\hline Rich Agric. Full & & & & \\
Bangladesh & -0.46 & -0.04 & 0.39 & -0.11 \\
Brazil & -3.16 & 0.39 & 0.97 & -1.80 \\
Chile & -5.42 & 0.01 & 1.51 & -3.90 \\
Colombia & -1.28 & 0.05 & 0.95 & -0.28 \\
Indonesia & -2.68 & 0.05 & 1.40 & -1.23 \\
Malawi & -0.05 & 0.05 & -0.74 & -0.74 \\
Mexico & -1.74 & 0.12 & 1.93 & 0.31 \\
Mozambique & -0.23 & -0.01 & 0.31 & 0.07 \\
Peru & -1.32 & 0.07 & 0.85 & -0.40 \\
Philippines & -2.35 & 0.32 & 1.27 & -0.76 \\
Thailand & -9.63 & 0.16 & 2.84 & -6.63 \\
Uganda & -0.01 & 0.00 & 0.05 & 0.04 \\
Venezuela & -0.17 & 0.00 & 0.42 & 0.25 \\
Vietnam & -0.13 & 0.05 & 0.31 & 0.23 \\
Zambia & -0.01 & 0.02 & 0.13 & 0.14 \\
& & & & \\
Average & -1.91 & 0.08 & 0.84 & -0.99 \\
AAV & 1.91 & 0.09 & 0.94 & 1.13 \\
Sign Cons. & -1.00 & 0.93 & 0.89 & -0.88 \\
Rich Agric. Doha & & & & \\
Average & -0.46 & 0.10 & 0.16 & -0.19 \\
AAV & 0.52 & 0.11 & 0.31 & 0.42 \\
Sign Cons. & -0.88 & 0.92 & 0.52 & -0.46 \\
\hline Soriand & & & &
\end{tabular}

Source: Authors' simulations

Note: The total results in this table differ from the RichAgrFull poverty results in Hertel et al. (2007) since the results in this paper are computed as part of a full liberalization experiment using the methodology of Harrison, Horridge and Pearson (1999). Thus the results in this table reflect interactions with agricultural policy reforms in the poor countries, as well as non-agriculture reforms. 
Table 10. Drivers of Poverty Change across Focus Regions under Poor Agricultural Reforms

\begin{tabular}{|c|c|c|c|c|c|c|c|c|c|c|c|c|}
\hline Countries & Land & $\begin{array}{l}\text { Ag. } \\
\text { Unskilled } \\
\text { Labor }\end{array}$ & $\begin{array}{l}\text { Ag. } \\
\text { Skilled } \\
\text { Labor }\end{array}$ & $\begin{array}{l}\text { Non-Ag. } \\
\text { Unskilled } \\
\text { Labor }\end{array}$ & $\begin{array}{l}\text { Non- } \\
\text { Ag } \\
\text { Skilled } \\
\text { Labor }\end{array}$ & $\begin{array}{c}\text { Wage } \\
\text { Labor } \\
\text { Unskilled }\end{array}$ & $\begin{array}{l}\text { Wage } \\
\text { Labor } \\
\text { Skilled }\end{array}$ & $\begin{array}{c}\text { Agricultural } \\
\text { Capital }\end{array}$ & $\begin{array}{c}\text { Non- } \\
\text { agricultural } \\
\text { Capital }\end{array}$ & Transfers & Taxes & $\begin{array}{c}\text { Cost } \\
\text { of } \\
\text { Living }\end{array}$ \\
\hline \multicolumn{13}{|l|}{$\begin{array}{l}\text { Poor Agric. } \\
\text { Full }\end{array}$} \\
\hline Bangladesh & -1.9 & -0.9 & -0.7 & 0.7 & 0.7 & 0.3 & 0.7 & -0.7 & 0.7 & 0.0 & -0.5 & -0.5 \\
\hline Brazil & 1.9 & 1.3 & 1.2 & -0.1 & -0.1 & 0.1 & -0.1 & 1.1 & -0.2 & 0.0 & 0.1 & 0.0 \\
\hline Chile & 3.0 & 1.6 & 1.5 & 0.1 & 0.0 & 0.4 & 0.0 & 1.5 & 0.0 & 0.0 & -0.2 & -0.1 \\
\hline Colombia & -0.7 & -0.3 & -0.3 & 0.3 & 0.2 & 0.2 & 0.2 & -0.3 & 0.3 & 0.0 & -0.2 & -0.5 \\
\hline Indonesia & 0.1 & 0.1 & 0.0 & 0.2 & 0.0 & 0.2 & 0.0 & 0.1 & 0.2 & 0.0 & -0.2 & -0.4 \\
\hline Malawi & 3.7 & 2.3 & 1.8 & 0.2 & -0.1 & 1.1 & -0.1 & 1.8 & -0.4 & 0.0 & -0.6 & -0.8 \\
\hline Mexico & -12.4 & -5.3 & -4.7 & 0.0 & 0.2 & -0.9 & 0.2 & -4.7 & 0.3 & 0.0 & 0.1 & -0.5 \\
\hline Mozambique & 3.4 & 2.3 & 2.0 & 0.8 & 0.7 & 1.2 & 0.7 & 2.1 & 0.7 & 0.0 & -0.9 & -1.2 \\
\hline Peru & -1.9 & -1.0 & -0.8 & 0.4 & 0.3 & 0.0 & 0.3 & -0.7 & 0.7 & 0.0 & -0.4 & -0.5 \\
\hline Philippines & -2.3 & -1.4 & -1.0 & 0.4 & 0.4 & -0.3 & 0.4 & -0.9 & 0.8 & 0.0 & -0.2 & -1.1 \\
\hline Thailand & 3.4 & 2.4 & 2.1 & 0.7 & 0.5 & 1.2 & 0.5 & 2.0 & 0.5 & 0.0 & -0.7 & -1.2 \\
\hline Uganda & 0.3 & 0.2 & 0.2 & 0.1 & 0.1 & 0.2 & 0.1 & 0.2 & 0.2 & 0.0 & -0.2 & -0.3 \\
\hline Venezuela & -1.6 & -0.7 & -0.7 & 0.3 & 0.2 & 0.1 & 0.2 & -0.7 & 0.3 & 0.0 & -0.2 & -0.2 \\
\hline Vietnam & 5.7 & 3.9 & 3.6 & 1.8 & 1.6 & 2.3 & 1.6 & 3.5 & 1.4 & 0.0 & -1.5 & -1.4 \\
\hline Zambia & -0.7 & -0.4 & -0.2 & 0.4 & 0.4 & 0.2 & 0.4 & -0.2 & 0.7 & 0.0 & -0.3 & -0.4 \\
\hline Average & -0.0 & 0.3 & 0.3 & 0.4 & 0.3 & 0.4 & 0.3 & 0.3 & 0.4 & 0.0 & -0.4 & -0.6 \\
\hline AAV & 2.9 & 1.6 & 1.4 & 0.4 & 0.4 & 0.6 & 0.4 & 1.4 & 0.5 & 0.0 & 0.4 & 0.6 \\
\hline Sign Cons. & -0.0 & 0.2 & 0.2 & 1.0 & 0.9 & 0.7 & 0.9 & 0.2 & 0.9 & 0.0 & -0.9 & -1.0 \\
\hline \multicolumn{13}{|l|}{$\begin{array}{l}\text { Poor Agric. } \\
\text { Doha }\end{array}$} \\
\hline Average & -0.09 & -0.04 & -0.03 & 0.01 & 0.02 & -0.01 & 0.02 & -0.03 & 0.01 & 0.00 & -0.01 & -0.06 \\
\hline AAV & 0.38 & 0.20 & 0.16 & 0.03 & 0.04 & 0.04 & 0.04 & 0.16 & 0.05 & 0.00 & 0.02 & 0.07 \\
\hline Sign Cons. & -0.24 & -0.22 & -0.18 & 0.50 & 0.53 & -0.16 & 0.53 & -0.20 & 0.26 & 0.00 & -0.42 & -0.90 \\
\hline
\end{tabular}


Table 11 Earnings-Driven Percent Change in the Poverty Headcount (\$1/day) across Developing Country Strata, when Poor Countries Reform Agric. Policies

\begin{tabular}{lrrrrrrr}
\hline Countries & Agric. & $\begin{array}{c}\text { Non- } \\
\text { Agric. }\end{array}$ & $\begin{array}{c}\text { Urban } \\
\text { Labor }\end{array}$ & $\begin{array}{c}\text { Rural } \\
\text { Labor }\end{array}$ & Transfer & $\begin{array}{c}\text { Urban } \\
\text { Diverse }\end{array}$ & $\begin{array}{c}\text { Rural } \\
\text { Diverse }\end{array}$ \\
\hline Poor Agric. & & & & & & & \\
Full & & & & & & & \\
\hline Bangladesh & 0.2 & -0.2 & 0.0 & 0.0 & 0.0 & 0.0 & -0.1 \\
Brazil & -0.1 & 0.0 & 0.0 & 0.0 & 0.0 & 0.0 & 0.0 \\
Chile & -0.8 & 0.0 & -0.1 & -0.1 & 0.0 & -0.2 & -0.2 \\
Colombia & 0.1 & -0.1 & 0.0 & 0.0 & 0.0 & 0.0 & 0.0 \\
Indonesia & -0.1 & -0.1 & 0.0 & 0.0 & 0.0 & 0.0 & -0.1 \\
Malawi & -0.6 & 0.0 & 0.0 & -0.1 & 0.0 & 0.0 & -0.2 \\
Mexico & 0.5 & 0.0 & 0.2 & 0.2 & 0.0 & 0.3 & 0.7 \\
Mozambique & -0.3 & -0.1 & 0.0 & -0.1 & 0.0 & -0.1 & -0.3 \\
Peru & 0.1 & -0.2 & 0.0 & 0.0 & 0.0 & 0.0 & 0.0 \\
Philippines & 0.5 & -0.1 & 0.0 & 0.0 & 0.0 & 0.3 & 0.6 \\
Thailand & -0.3 & 0.0 & 0.0 & -0.2 & 0.0 & -0.2 & -1.9 \\
Uganda & 0.0 & 0.0 & 0.0 & 0.0 & 0.0 & 0.0 & 0.0 \\
Venezuela & 0.0 & -0.1 & -0.1 & 0.0 & 0.0 & 0.0 & 0.0 \\
Vietnam & -0.1 & -0.2 & 0.0 & 0.0 & 0.0 & -0.2 & -1.0 \\
Zambia & 0.0 & -0.1 & -0.1 & 0.0 & 0.0 & 0.0 & 0.0 \\
& & & & & & & \\
Average & -0.1 & -0.1 & 0.0 & 0.0 & 0.0 & 0.0 & -0.2 \\
AAV & 0.2 & 0.1 & 0.0 & 0.1 & 0.0 & 0.1 & 0.3 \\
Sign Cons. & -0.3 & -1.0 & -0.2 & -0.3 & -0.9 & -0.2 & -0.5 \\
Poor Agric. & & & & & & & \\
Doha & & & & & & & \\
Average & 0.0 & 0.0 & 0.0 & 0.0 & 0.0 & 0.0 & 0.0 \\
AAV & 0.0 & 0.0 & 0.0 & 0.0 & 0.0 & 0.0 & 0.0 \\
Sign Cons. & -0.1 & -0.5 & -0.6 & -0.2 & 0.1 & 0.2 & 0.6 \\
\hline Source: Authors' simulations & & & & & & \\
\end{tabular}

Source: Authors' simulations 
Table 12. Earnings-Driven Percent Change in the Poverty Headcount (\$1/day) across Developing Country Stratums, when Poor Countries Reform Agriculture

\begin{tabular}{lrrrr}
\hline & Earnings & Taxes & $\begin{array}{c}\text { Cost } \\
\text { Of } \\
\text { Living }\end{array}$ & Total \\
\hline Poor Agric. Full & & & & \\
Bangladesh & -0.10 & 0.56 & -0.63 & -0.17 \\
Brazil & -0.15 & -0.05 & 0.05 & -0.15 \\
Chile & -1.36 & 0.19 & -0.24 & -1.41 \\
Colombia & -0.03 & 0.14 & -0.39 & -0.28 \\
Indonesia & -0.30 & 0.39 & -0.92 & -0.83 \\
Malawi & -0.85 & 0.32 & -0.43 & -0.96 \\
Mexico & 1.84 & -0.15 & -1.08 & 0.61 \\
Mozambique & -0.78 & 0.48 & -0.78 & -1.08 \\
Peru & -0.07 & 0.34 & -0.50 & -0.23 \\
Philippines & 1.36 & 0.40 & -2.33 & -0.57 \\
Thailand & -2.61 & 1.02 & -2.96 & -4.55 \\
Uganda & -0.04 & 0.04 & -0.06 & -0.06 \\
Venezuela & -0.11 & 0.25 & -0.29 & -0.15 \\
Vietnam & -1.42 & 1.13 & -1.42 & -1.71 \\
Zambia & -0.19 & 0.17 & -0.27 & -0.29 \\
& & & & \\
Average & -0.32 & 0.35 & -0.82 & -0.79 \\
AAV & 0.75 & 0.38 & 0.82 & 0.87 \\
Sign Cons. & -0.43 & 0.93 & -0.99 & -0.91 \\
Poor Agric. Doha & & & & \\
Average & 0.01 & 0.01 & -0.10 & -0.07 \\
AAV & 0.07 & 0.03 & 0.11 & 0.09 \\
Sign Cons. & 0.07 & 0.56 & -0.88 & -0.83 \\
\hline So A & & & &
\end{tabular}

Source: Authors' simulations

Note: The total results in this table differ from the RichAgrFull poverty results in Hertel et al. (2007) since the results in this paper are computed as part of a full liberalization experiment using the methodology of Harrison, Horridge and Pearson (1999). Thus the results in this table reflect interactions with agricultural policy reforms in the poor countries, as well as non-agriculture reforms. 
Table 13. Percentage change in the $\$ 1 /$ day Head Count under Full Reforms

\begin{tabular}{lrrrrr}
\hline Countries & $\begin{array}{c}\text { Rich } \\
\text { Agric. } \\
\text { Reforms }\end{array}$ & $\begin{array}{c}\text { Poor } \\
\text { Agric. } \\
\text { Reforms }\end{array}$ & $\begin{array}{c}\text { Subtotal } \\
\text { Agric. } \\
\text { Reforms }\end{array}$ & $\begin{array}{c}\text { Subtotal } \\
\text { Non-Agric. } \\
\text { Reforms }\end{array}$ & Total \\
\hline Bangladesh & -0.11 & -0.18 & -0.29 & 0.57 & 0.28 \\
Brazil & -1.79 & -0.15 & -1.94 & 0.53 & -1.41 \\
Chile & -3.89 & -1.41 & -5.30 & 0.31 & -4.99 \\
Colombia & -0.29 & -0.28 & -0.57 & 0.67 & 0.10 \\
Indonesia & -1.24 & -0.82 & -2.06 & 0.61 & -1.45 \\
Malawi & -0.74 & -0.96 & -1.70 & -0.14 & -1.84 \\
Mexico & 0.31 & 0.61 & 0.92 & 0.43 & 1.35 \\
Mozambique & 0.07 & -1.08 & -1.01 & 0.32 & -0.69 \\
Peru & -0.40 & -0.23 & -0.63 & -0.16 & -0.79 \\
Philippines & -0.76 & -0.56 & -1.32 & 0.57 & -0.75 \\
Thailand & -6.63 & -4.55 & -11.18 & 2.31 & -8.87 \\
Uganda & 0.04 & -0.06 & -0.02 & 0.08 & 0.06 \\
Venezuela & 0.26 & -0.15 & 0.11 & 0.75 & 0.86 \\
Vietnam & 0.22 & -1.70 & -1.48 & -4.37 & -5.85 \\
Zambia & 0.14 & -0.29 & -0.15 & 0.24 & 0.09 \\
& & & & & \\
Average & -0.99 & -0.79 & -1.77 & 0.18 & -1.59 \\
AAV & 1.13 & 0.87 & 1.91 & 0.80 & 1.96 \\
Sign Cons. & -0.88 & -0.91 & -0.93 & 0.23 & -0.81 \\
\hline Source: Authors' simulations & & & &
\end{tabular}


Table 14. Percentage change in the $\$ 1 /$ day Head Count under Doha Reforms

\begin{tabular}{lrrrrr}
\hline Countries & $\begin{array}{c}\text { Rich } \\
\text { Agric. } \\
\text { Reforms }\end{array}$ & $\begin{array}{c}\text { Poor } \\
\text { Agric. } \\
\text { Reforms }\end{array}$ & $\begin{array}{c}\text { Subtotal } \\
\text { Agric. } \\
\text { Reforms }\end{array}$ & $\begin{array}{c}\text { Subtotal } \\
\text { Non-Agric. } \\
\text { Reforms }\end{array}$ & Total \\
\hline Bangladesh & 0.00 & -0.01 & -0.01 & -0.03 & -0.04 \\
Brazil & -0.72 & -0.04 & -0.76 & -0.04 & -0.80 \\
Chile & -0.99 & -0.30 & -1.29 & 0.00 & -1.29 \\
Colombia & -0.17 & 0.01 & -0.16 & 0.06 & -0.10 \\
Indonesia & -0.13 & 0.07 & -0.06 & -0.14 & -0.20 \\
Malawi & 0.41 & -0.06 & 0.35 & 0.01 & 0.36 \\
Mexico & 0.15 & -0.13 & 0.02 & 0.11 & 0.13 \\
Mozambique & 0.05 & -0.05 & 0.00 & 0.02 & 0.02 \\
Peru & 0.04 & 0.00 & 0.04 & 0.02 & 0.06 \\
Philippines & 0.02 & 0.00 & 0.02 & -0.27 & -0.25 \\
Thailand & -1.42 & -0.35 & -1.77 & -0.20 & -1.97 \\
Uganda & 0.04 & 0.00 & 0.04 & 0.00 & 0.04 \\
Venezuela & 0.12 & -0.05 & 0.07 & 0.14 & 0.21 \\
Vietnam & 0.14 & -0.21 & -0.07 & 0.96 & 0.89 \\
Zambia & 0.03 & -0.01 & 0.02 & 0.01 & 0.03 \\
& & & & & \\
Average & -0.16 & -0.08 & -0.24 & 0.04 & -0.19 \\
AAV & 0.30 & 0.09 & 0.31 & 0.13 & 0.43 \\
Sign Cons. & -0.55 & -0.86 & -0.76 & 0.32 & -0.46 \\
\hline Source: Authors' simulations & & & &
\end{tabular}

